\title{
Localizing Climate Change Action
}

\section{Myanna Dellinger*}

\begin{abstract}
Waiting for national- and supranational-level actors to reach a broadly based and substantively effective agreement on climate change mitigation is like waiting for Godot-unlikely to happen, at least at a substantively early enough point in time. The December 2012 negotiations under the United Nations Framework Convention on Climate Change (UNFCCC) umbrella yet again demonstrated the problem in seeking widely accepted action from close to two hundred nations with widely divergent interests in climate change and the related underlying issues. This article adds new value to existing scholarship by conducting original research into select climate initiatives at the sub-national, sub-state level in order to find out whether it is worth pursuing climate change action at this level instead. The article posits that in times with little or severely delayed climate change action by national and supranational actors, it is worth pursuing climate change action at the local-but not the purely private-level.

After identifying what "success" means in the climate change arena, the article analyzes the potential for both substantive and procedural success presented by select local initiatives. Some of these feature traditional adversarial enforcement methods, some feature modern collaborative-style enforcement, some feature no enforcement at all, and one is a

(C) 2013 Myanna Dellinger

* After a successful first career in international communications and university instruction on two continents, Professor Dellinger graduated from law school at the top of her class from the University of Oregon School of Law (Order of the Coif). While in law school, she interned for the United Nations Framework Convention for Climate Change. After law school, she clerked for the late Hon. Francis J. D'Eramo of the Superior Court of the United States Virgin Islands and for the Hon. Procter Hug, Jr., of the United States Court of Appeals for the Ninth Circuit. She is currently an Assistant Professor of Law with Western State College of Law. She has visited thirty-three nations for business and pleasure.
\end{abstract}


reporting program with mandatory implications. This article demonstrates how action at the scaled-down level can be effective whether traditional adversarial, or more collaborative goal enforcement methods are applied, and perhaps even if no enforcement methods are applied at all.

The article builds on the author's parallel project, An Unstoppable Tide: Creating Environmental and Human Rights Law from the Bottom Up. ${ }^{1}$ This article analyzes bottom-up, polycentric developments within national and international environmental and human rights law in general. It argues that bottom-up, polycentric action presents viable alternatives to traditional top-down action within these areas and presents a set of guidelines for the development and enforcement of law that apply to action within climate change and thus to this article as well.

I. Introduction 605

II. The Current State of Affairs.

A. The Science. 607

B. The Economy 610

C. The Lacking Political and Legal Action .....................613

III. Local Climate Change Experiments .................................6 616

A. Experiments with Traditional Enforcement

Methods

1. EU Covenant of Mayors

2. Carbon Rationing Action Groups (CRAGs)........ 619

B. Experimenting with Collaborative Enforcement

Methods

C. Voluntary Experiments ............................................ 632

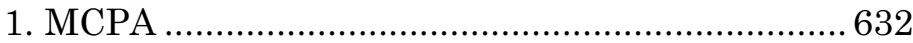

2. ICLEI and the GreenClimateCities Initiative..... 634

D. Interim Lessons Learned from City Coalition

Programs .............................................................. 638

E. Reporting with Mandatory Implications................... 641

IV. What Does "Success" Mean Within the Climate Change

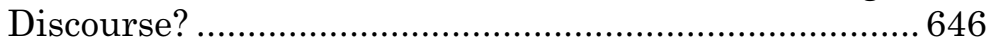

A. Benchmarks for Success ...........................................646 646

B. Can Local Action Be "Too Successful"? .....................649

1. Myanna Dellinger, An Unstoppable Tide: Creating Environmental and Human Rights Law from the Bottom Up, 15 OR. REV. INT'L L. (forthcoming 2013). 
V. The Status: Is It Worth Pursuing Climate Change

Action at the Localized Level? 651

A. Action at the Private, Voluntary Level: CRAGs and the Nudge Theory

B. Action at the City Level: EU Covenant of Mayors and GreenClimateCities

C. Action at the Established NGO-Level: Climate Savers 662

D. Multi-Sector Action: The Climate Registry ...............664 664

VI. Conclusion 666

Everybody talks about the weather, but nobody does anything about it. ${ }^{2}$

\section{INTRODUCTION}

Fortunately, the above saying is no longer true. Some attempts have been and are made around the world to curb climate change. ${ }^{3}$ Unfortunately, these have produced very few actual, promising results so far. ${ }^{4}$ Numerous scholarly articles have been written lamenting the lack of effective action at, in particular, the state, national, or supranational level and discussing the need for local action instead. 5 This article builds on such scholarship, but adds new value by conducting original research into select climate initiatives at the sub-national, substate level in order to analyze whether it is worth pursuing

2. Quote is commonly attributed to either Mark Twain or Charles Dudley Warner.

3. See, e.g., Plastic Bag Ban in LA Approved by City Council, Paper Bags to be 10 Cents, HUfFington Post (May 23, 2012, 4:00 PM), http://www.huffingtonpost.com/2012/05/23/plastic-bag-ban-la_n_1540478.html [hereinafter Plastic Bag Ban] (discussing Los Angeles' efforts to encourage citizens not to use plastic bags); Andrew Winston, The Challenge of Climate Math, HufFington Post (Nov. 26, 2012, 11:04 AM), http://www. huffingtonpost.com/andrew-winston/the-challenge-of-climate-_b_2189004.html (discussing different global efforts toward environmental conservation).

4. See Wynne Parry, UNEP Greenhouse Gas Emissions Report Finds Climate Change Goals Growing More Elusive, Huffington Post (Nov. 23, 2012, 5:51 PM), http://www.huffingtonpost.com/2012/11/23/unep-greenhousegas-emissions_n_2179270.html.

5. See, e.g., Robert B. McKinstry, Jr., Laboratories for Local Solutions for Global Problems: State, Local, and Private Leadership in Developing Strategies to Mitigate the Causes and Effects of Climate Change, 12 PENN ST. ENVTL. L. REV. 15, 16-28 (2004) (discussing the effectiveness of local government and private groups in filling the voids left the Federal Government in fighting climate change). 
climate change action at this scale at all. To do so, the article analyzes the particular factors that are considered to make environmental law initiatives successful as well as risk factors of which both law and policymakers should be aware. The article is among the first to set forth a framework of reference for analyzing what "success" means in the environmental law context with a particular focus on climate change and to apply this framework to the analysis of programs to analyze whether they may be considered effective currently or have the potential for being so in the future. Since this appears to be the case for most programs, the article posits that in times with little or delayed climate change action by national and supranational actors, it is worth pursuing climate change action at the localbut not the purely private-level. Further, the article shows how action at the scaled-down level can be effective whether traditional adversarial or more collaborative goal enforcement methods are applied, or perhaps even where no enforcement methods are applied at all.

The article builds on the author's parallel project, $A n$ Unstoppable Tide: Creating Environmental and Human Rights Law from the Bottom Up. ${ }^{6}$ The parallel article analyzes bottomup, polycentric developments within national and international environmental and human rights law. ${ }^{7}$ It posits that such action presents viable alternatives to traditional top-down action and describes why. ${ }^{8}$ The article presents value in the form of a set of guidelines from the human rights and environmental law arenas that can be applied to future developments of modern law in both arenas, but also in more specialized segments of the law such as climate change action. ${ }^{9}$ As described in the author's parallel article, clear comparisons between human rights and climate change can be drawn. ${ }^{10}$ For example, severe weather caused by climate change may affect our health and ultimately our lives, thus impacting the human rights to health and life. Our property rights may be at peril because of climate change as well.11 In 2008, the UN Human

6. Dellinger, supra note 1 (manuscript at 2 ).

7. Id.

8. Id.

9. Id. (manuscript at $76-90)$.

10. Id. (manuscript at 38-41).

11. See, e.g., Alexandra B. Klass \& Elizabeth J. Wilson, Climate Change, Carbon Sequestration, and Property Rights, 2010 U. ILL. L. REV. 363, 377-86 
Rights Council officially recognized the fact that "climate change poses an immediate and far-reaching threat to people and communities around the world and has implications for the full enjoyment of human rights." 12 Accordingly, the principles for law creation, observance, and enforcement produced in the parallel article apply to the present article as well; as do the guidelines set forth in that article for effective law creation at the scaled-down and potentially non-governmental level.

While we discuss what to do and how best to do it, the climate situation keeps getting more and more dire. ${ }^{13} \mathrm{We}$ already let several precious years go by without any real progress in the area. ${ }^{14}$ The severity of this will be set forth in Part II by way of a brief factual background.

\section{THE CURRENT STATE OF AFFAIRS}

This article takes the starting point that climate change exists, is manmade, and needs to be addressed effectively now-within a few years at the most-in order to avoid severe planetary effects. The article will thus not re-discuss that body of knowledge other than providing the following update of the state of scientific, economic, and legal affairs to demonstrate the now extreme urgency of the problem.

\section{A. THE SCIENCE}

In May 2012, the National Oceanic and Atmospheric Administration's (NOAA) National Climatic Data Center released a report showing that the average temperature in the United States between March and May was $57.1^{\circ} \mathrm{C}$, which is $5.2^{\circ} \mathrm{C}$ above the long-term average from 1901 to $2000 .{ }^{15}$ Before

(discussing issues that may arise as carbon sequestration becomes an attractive solution to limit the amount of carbon dioxide in the atmosphere, and specifically pointing out the property issues that arise when the government wants to store the carbon dioxide in pores beneath citizens' land).

12. Human Rights and Climate Change, Human Rights Council, 7th Sess., at 1, U.N. Doc. A/HRC/7/L.21/Rev.1 (Mar. 26, 2008).

13. See generally Bill McKibben, Global Warming's Terrifying New Math, Rolling STONE, Aug. 2, 2012, at 52, 53-60 (discussing the climate goals that must at a minimum be met and why that might not even be enough); Parry, supra note 4.

14. See Parry, supra note 4 (pointing out that as countries continue to make pledges to lower carbon emissions, the gap between those pledges and the level of reductions to cap global warming at $2^{\circ} \mathrm{C}$ is widening, and that greenhouse gas emissions may already be at such a high level that we may not be able to avert the worst consequences of global warming).

15. Michael Pearson \& Phil Gast, More Record Warmth as Scientists Warn 
May 2012, the United States experienced twelve consecutive months with temperatures in the top third of recorded monthly average temperatures. ${ }^{16}$ The odds of that happening randomly are 1 in 540,000.17 Globally, the average April 2012 temperature was $1.17^{\circ} \mathrm{C}$ warmer than the average from the past century. ${ }^{18}$ That was the 327 th consecutive month that global temperatures exceeded the 20th century average. 19 The odds of that happening by simple chance are higher "than the number of stars in the universe." 20 NASA scientist James Hansen, the "Godfather of Global Warming," 21 states that the likelihood of temperatures similar to the global heat waves of recent years was rarer than 1 in 300 from the 1950s through the $1980 \mathrm{~s} .{ }^{22}$ Now, the odds are closer to 1 in $10 .{ }^{23} \mathrm{Mr}$. Hansen stated that "statistically what's happening is not random or normal, but pure and simple climate change." 24 The United States Supreme Court and at least two United States Courts of Appeals have taken note of this. ${ }^{25}$

of Global Tipping Point, CNN.COM (June 8, 2012, 5:37 PM), http://articles.cnn.com/2012-06-08/us/us_record-warmth_1_climate-changenoaa-nature-article?_s=PM:US.

16. Id.

17. $I d$.

18. Id.

19. $I d$.

20. McKibben, supra note 13, at 52 (this figure was based on 327 consecutive months of above average temperatures including May 2012).

21. New Study Links Current Events to Climate Change, INDEPENDENTMAIL.COM (Aug. 4, 2012), http://www.independentmail.com/ news/2012/aug/04/new-study-links-current-events-climate-change/?print=1.

22. Doyle Rice, NASA Scientist Ties Heat Waves to Global Warming, USA TODAY (Aug. 4, 2012), http://usatoday30.usatoday.com/weather/climate/ globalwarming/story/2012-08-04/heat-waves-climate-change-jameshansen/56794570/1.

23. $I d$.

24. New Study Links Current Events to Climate Change, supra note 21.

25. See, e.g., Massachusetts v. EPA, 549 U.S. 497, 504-05 (2007) (noting that in recent decades, "[a] well-documented rise in global temperatures has coincided with a significant increase in the concentration of [greenhouse gases] in the atmosphere"); Coal. for Responsible Regulation, Inc. v. EPA, 684 F.3d 102, 120-21 (D.C. Cir. 2012) (similarly relying on the EPA's "substantial scientific evidence" showing that "anthropogenically induced climate change threatens both public health and public welfare" and commenting that "[t]his is how science works, and, additionally, the EPA is not required to re-prove the existence of the atom every time it approaches a scientific question"); Native Vill. of Kivalina v. Exxon Mobil, 696 F.3d 849, 857, 858 (9th Cir. 2012) (referring to the "dire circumstance" in which the village of Kivalina finds itself because of the rising sea level caused by climate change, but relying on 
What must be done about this problem? The 2007 International Panel on Climate Change (IPCC) Synthesis Report stated that to keep the global average temperature increase from pre-industrial levels within $2-2.4^{\circ} \mathrm{C}$, carbon dioxide $\left(\mathrm{CO}_{2}\right)$ emissions must be reduced by $50-85 \%$ from 2000 levels by 2050 and peak by $2015 .^{26}$ The " 167 countries responsible for more than 87 percent of the world's carbon emissions have signed on to the Copenhagen Accord, endorsing the two-degree target," which is just about "the only thing about climate change that the world has settled on."27 The 2012 Doha agreement reached under the auspices of the United Nations Framework Conference for Climate Change (UNFCCC) reaffirmed the two degree target. ${ }^{28}$ But it is looking more and more unlikely that goal can be met. For example, the concentration of $\mathrm{CO}_{2}$ in the atmosphere has, according to a 2012 UN report, jumped 20\% since 2000.29 Additionally, an individual would have to have a footprint of no more than 1.1 metric tons of $\mathrm{CO}_{2}$ from their direct energy use to allow for an $80 \%$ reduction by $2050 .{ }^{30}$ As an illustration, individuals in the United States produced 18.6 metric tons of $\mathrm{CO}_{2}$ per person in $2008 .{ }^{31}$ In total amounts, one calculation shows that global

Connecticut v. Am. Elec. Power Co., 131 S. Ct. 2527, 2534 (2011) in holding that relief must come from the legislative and executive branches of the government, not the courts via federal common law nuisance claims).

26. Intergovernmental Panel on Climate Change, Climate Change 2007: SyNTHESIS REPORT 67 (R.K. Pachauri \& A. Reisinger eds., 2007). In 2011, the chief economist for the International Energy Agency projected that current global energy consumption levels put the Earth on a trajectory to warm by $6^{\circ} \mathrm{C}$ above pre-industrial levels by 2100 , an outcome he called "a catastrophe for all of us." Juliet Eilperin, World on Track for Nearly 11-Degree Temperature Rise, Energy Expert Says, WASH. POST (Nov. 28, 2011), http://www.washingtonpost.com/national/health-science/world-on-track-fornearly-11-degree-temperature-rise-energy-expert-

says/2011/11/28/gIQAi0lM6N_story.html (mentioning the "2 degree" goal).

27. McKibben, supra note 13, at 55 .

28. Ban Welcomes Outcome of UN Climate Change Talks in Doha, UNITED NATIONS NEWS CENTRE (Dec. 8, 2012), http://www.un.org/apps/news/ story.asp?NewsID=43716\#.UMjE1454VW4.

29. Karl Ritter, 2012 UN Climate Talks in Doha, Qatar Face Multiple Challenges, HUFFINGTON POsT (Nov. 25, 2012, 10:51 AM), http://www.huffingtonpost.com/2012/11/25/2012-un-climate-talksqatar_n_2188048.html.

30. RACHel Howell, UK Energy Research CEntre, The Experience OF CARBON RATIONING ACTION GROUPS: IMPLICATIONS FOR A PERSONAL CARBON AllOWANCES POLICY 19 (2009), available at http://www.eci.ox.ac.uk/ publications/downloads/howell09crags.pdf.

31. CO2 Emissions, WORLD BANK, http://data.worldbank.org/indicator/ 
anthropogenic emissions must be reduced to approximately 44 metric gigatons of $\mathrm{CO}_{2}$ equivalent $\left(\mathrm{GtCO}_{2} \mathrm{e}\right)$ by 2020 to stay within the $2^{\circ} \mathrm{C}$ goal. ${ }^{32}$ However, at the end of 2009 , total global greenhouse gas (GHG) emissions amounted to $49.5 \mathrm{GtCO}_{2} \mathrm{e} .{ }^{33}$ The emissions gap between what is necessary to avoid catastrophic climate change and projected emissions continues to widen instead of narrow. ${ }^{34}$ Thus, it may already have become unrealistic to strive for "only" a $2^{\circ} \mathrm{C}$ limit. ${ }^{35}$ Indeed, a recent World Bank projection showed that temperatures are more likely to increase up to $4^{\circ} \mathrm{C}$ by the end of this century over preindustrial times, thus overshooting the target on which most UN talks have been based so far. ${ }^{36}$ The chief economist of the International Energy Agency cites to evidence showing that temperatures are likely to rise by $11^{\circ} \mathrm{C}$, "which would create a planet straight out of science fiction." 37 In fact, temperatures have already risen by almost $0.8^{\circ} \mathrm{C}$ and, because of previously released carbon is likely to rise another $0.8^{\circ} \mathrm{C}$, the world is already three-quarters of the way to the "bottomest of bottom lines" two-degree target. 38 The world can afford to add only approximately "565 more gigatons of carbon dioxide into the atmosphere by midcentury and still have some reasonable hope of staying below two degrees. ('Reasonable,' in this case, means four chances in five, or somewhat worse odds than playing Russian roulette with a six-shooter.)"39

\section{B. THE ECONOMY}

The above description paints a very bleak picture of the state of affairs and the uphill battle to be fought. Perhaps it is already too late to realistically hope for effective mitigation of

EN.ATM.CO2E.PC (last visited Feb. 12, 2013) (showing per capita emission levels reflecting the burning of fossil fuels and manufacture of cement by nation and year).

32. United NATions ENVIRONMENT PROgRAMME, BRIDGing THE EMISSIONS GAP: A UNEP SYNTHESIS REPORT 9, 16 (2011), available at http://www.unep.org/pdf/UNEP_bridging_gap.pdf.

33. Id. at 15 .

34. Parry, supra note 4.

35. See id.

36. Ritter, supra note 29.

37. McKibben, supra note 13 , at 55 .

38. Id. at $54-55$.

39. Id. at 55 . 
the problem. ${ }^{40}$ Perhaps adaptation is the best we can do at this point in time. ${ }^{41}$ However, the problem is too severe to simply give up even trying. ${ }^{42}$ Further, relatively sudden and effective turn-arounds of severe scientific and moral problems of international importance have been seen before. For example, extensive campaigning in the 1980s demanded and obtained financial divestment from companies doing business in South Africa because of the apartheid problem. ${ }^{43}$ Currently, campaigns against sweat shops and child labor appear to add leverage against companies acquiring products produced in morally reprehensible ways. ${ }^{44}$ The ozone layer problem was virtually resolved by the Montreal Protocol in a relatively short amount of time. 45 However, one major difference between the ozone depletion problem and climate change is that with the ozone problem, President Reagan embraced aggressive action at an early point in time to solve the problem because of a belief in the cost-benefit analysis which, at bottom, made action cheaper than inaction. ${ }^{46}$ In contrast, the financial advantages of taking action against climate change have not yet become persuasive, at least in the United States, although one can hope that this will change with more awareness of the financial benefits of taking action. ${ }^{47}$ For example, the size of the "climate economy" is estimated to be $\$ 2.2$ trillion by 2020.48 Other countries are taking note of this: China's budget for energy

40. See Parry, supra note 4.

41. See McKibben, supra note 13, at 57 ("Changes to weather patterns that move crop-production areas around - we'll adapt to that." (quoting Exxon CEO, Rex Tillerson)).

42. See, e.g., Parry, supra note 4 (discussing the importance of avoiding a $4^{\circ} \mathrm{C}$ jump, and noting that although difficult, it is still possible to avoid).

43. McKibben, supra note 13, at 60.

44. See generally B.J. Bullert, Strategic Public Relations, Sweatshops, and the Making of a Global Movement (Joan Shorenstien Ctr., Working Paper No. 14, 2000), available at http://shorensteincenter.org/wp-content/uploads/ 2012/03/2000_14_bullert.pdf (discussing campaigns against Nike's sweatshops).

45. See, e.g., Frances Beinecke, Solving the Ozone Layer: Lessons for Fighting Climate Change, NAT'L RES. DeF. CouncIL (Sept. 14, 2012), http://switchboard.nrdc.org/blogs/fbeinecke/saving_the_ozone_layer_lessons.ht $\mathrm{ml}$.

46. See Winston, supra note 3.

47. See McKibben, supra note 13, at 52-53 (observing the fact that President Obama chose not to attend the twentieth anniversary reprise of an environmental summit in Rio that was previously attended by President George H.W. Bush).

48. Winston, supra note 3. 
conservation and anti-pollution measures over the next few years is $\$ 372$ billion. ${ }^{49}$ In contrast, the global clean energy investment in 2011 was $\$ 260$ billion. ${ }^{50}$ Saudi Arabia is planning to invest $\$ 109$ billion in its solar industry over the next twenty years. ${ }^{51}$ Frequently cloudy Germany has, through early and focused investments, become the world leader in solar power whereas most parts of sunny America are only now rolling out solar programs, but arguably still only at a negligible scale given the abundance of the natural resource. ${ }^{52}$

A very significant obstacle to climate change solutions is precisely the carbon economy and the companies, even nations, who are heavily invested in this. ${ }^{53}$ Whereas we can add only 565 gigatons of fossil fuels to stay within the world recognized $2^{\circ} \mathrm{C}$ goal, the carbon contained in the proven coal, oil, and gas reserves of fossil-fuel companies and the countries that act as such-e.g., Venezuela and Kuwait-amounts to 2,795 gigatons; five times more than the "safe" limit.54 Those reserves are the primary assets-worth approximately $\$ 27$ trillion-of oil companies, such as ExxonMobile or Lukoil.55 If the reserves of these firms were all to be burned, "[they] would use up more than a quarter of the remaining two-degree budget." 56 These companies are obviously not going to give up on such lucrative assets and further opportunities for growth in their fields, and are doing quite the opposite: in March 2012, "Exxon CEO Rex Tillerson told Wall Street analysts that the company plans to spend $\$ 37$ billion a year through 2016 (about $\$ 100$ million a day) searching for yet more oil and gas." 57 This industry alone holds the power to change the chemistry of our planet, and it is

\footnotetext{
49. Id.

50. $I d$.

51. Id.

52. See id. (noting that during one sunny day in May, Germany was able to supply fifty percent of the nations required power through its solar energy network-a world record); see also Herman K. Trabish, Sunshot Program: Your Tax Dollars at Work Growing Solar, GREEN TECH MEDIA (Apr. 23, 2012), http://www.greentechmedia.com/articles/read/SunShot-Program-Your-TaxDollars-at-Work-Growing-Solar.

53. See Jeff Coelho, Analysis: Climate Impasse Could Kill Carbon Offset Investment, REUTERS (Oct. 31, 2011, 12:31 PM), http://www.reuters.com/ article/2011/10/31/us-cdm-investment-climate-idUSTRE79U4YA20111031.

54. McKibben, supra note 13 , at 55-56.

55. Id. at 56 .

56. Id. at 57 .

57. $I d$.
} 
planning to use it. As for the advice by the business sector in general as to what to do "if" scientists turn out to be correct, the position of the U.S. Chamber of Commerce is simply that "populations can acclimatize to warmer climates via a range of behavioral, physiological and technological adaptations." 58 This problem is extreme indeed and clearly needs to be addressed somehow, whether through legislative action, hopeless as it may seem currently given the sheer strength of the carbon industry, or through investor-driven and other action.

\section{The Lacking Political And Legal Action}

Although time is running out quickly, there is still a very small window of time in which to act to attempt to avoid at least the very worst effects of climate change. However, taking beneficial advantage of this window will require swift and decisive action by a multitude of actors around the world at multiple scales. Until recently, focus was largely on national and multinational actors who were largely perceived to be "the only game in town." 59 The problem with climate change at that scale is, however, the continued lack of effective, promising action. The Kyoto Protocol only called for at least 5\% GHG reductions by Annex I nations under the first commitment period; 60 not nearly enough to effectively stem climate change according to current data. ${ }^{61}$ And although the Kyoto Protocol was extended from 2012 to 2020 at the 2012 Conference of Parties (COP 18) in Doha, ${ }^{62}$ only 37 out of the 191 parties to the UNFCCC now have legally binding emissions limitations and reduction commitments, representing only about $15 \%$ of global emissions. ${ }^{63}$ The Kyoto Protocol now mainly applies to the

58. Id. at 58 .

59. Thomas Gremillion, Setting the Foundation: Climate Change Adaptation at the Local Level, 41 ENVTL. L. 1221, 1229 (2011).

60. Kyoto Protocol to the United Nations Framework Convention on Climate Change, art. 3, Dec. 11, 1997, 2303 U.N.T.S. 162.

61. See supra Part II.A.

62. Outcome of the Work of the Ad Hoc Working Group on Further Commitments for Annex I Parties Under the Kyoto Protocol, Draft Decision, 8th Sess., Nov. 26, 2012-Dec. 7, 2012, U.N. Doc. FCCC/KP/CMP/2012/L.9 (Dec. 8, 2012) [hereinafter Ad Hoc Working Group on Further Commitments]; Ban Welcomes Outcome of UN Climate Change Talks in Doha, UNITED NATIONS NEWS CENTRE (Dec. 8, 2012), http://www.un.org/apps/news/ story.asp?NewsID=43716\#.UMjE1454VW4.

63. Ban Welcomes Outcome of UN Climate Change Talks in Doha, supra note 62; Karl Ritter \& Michael Casey, UN Climate Conference: Kyoto Protocol Extended at Doha, Qatar Talks, HuFfington Post (DEC. 8, 2012, 4:33 AM), 
European Union (EU), Australia, and a few other countries who can choose their own emission targets. ${ }^{64}$ Previous industrialized signatories Japan, Russia, and Canada did not sign on to the extension. ${ }^{65}$ The United States signed but never ratified the Kyoto Protocol. 66 Cautious hopes before Doha had been for a newly strengthened and legally binding agreement that would also apply to developing countries such as China and India, the world's top and third largest carbon emitters, respectively. ${ }^{67}$ But at a time when the Kyoto Protocol should have been strengthened, it was left significantly weakened, although officially still alive. ${ }^{68}$ And although a "rough work plan" attempts to pave the way for a comprehensive, legally binding agreement by 2015 , it would only take effect in 2020 ; years after carbon emissions should already have peaked.69 After the Copenhagen, Durban, and Doha UNFCCC negotiations, there is thus-for good reason-wide and deep skepticism regarding the efficacy of large-scale international solutions to be implemented through national actors. ${ }^{70}$

At the regional level, the EU has adopted relatively farreaching climate change reduction commitments-"cutting its emissions to $20 \%$ below 1990 levels" by 202071_but has

http://www.huffingtonpost.com/2012/12/08/un-climate-conference-kyoto-dohaqatar_n_2262371.html.

64. Tom Arup, Doha Climate Change Talks Delivered Little, SYDNEY MORNING HERALD (Dec. 11, 2012), http://www.smh.com.au/environment/dohaclimate-change-talks-delivered-little-20121210-2b5oj.html.

65. Id.

66. Status of Ratification of the Kyoto Protocol, UNFCC, http://unfccc.int/ kyoto_protocol/status_of_ratification/items/2613.php (last visited Mar. 23, 2012); Michael A. Fletcher \& Juliet Eilperin, Bush Proposes Talks on Warming, WASH. POST (May 31, 2007), http://www.washingtonpost.com/wpdyn/content/article/2007/05/31/AR2007053100934.html ("Bush refused to ratify the Kyoto Protocol, which required industrialized nations to bring greenhouse gas emissions below 1990 levels by 2012, calling the plan -- which excluded many fast-growing countries such as India and China -unworkable.").

67. Gopal Sharma, India Says is Now Third Highest Carbon Emitter, REUTERS (Oct. 4, 2010, 9:12 AM), http://www.reuters.com/article/2010/10/ 04/us-india-climate-idUSTRE6932PE20101004.

68. Stephen Leahy, Doha Climate Summit Ends with No New CO2 Cuts or Funding, TRUTHOUT (Dec. 10, 2012, 2:16 PM), http://truth-out.org/news/ item/13254-doha-climate-summit-ends-with-no-new-co2-cuts-or-funding.

69. Arup, supra note 64.

70. See Ritter \& Casey, supra note 63.

71. What is the EU Doing About Climate Change?, Eur. Commission, http://ec.europa.eu/clima/policies/brief/eu/index_en.htm (last updated Jan. 7, 
admitted that because the EU is a relatively small group of emitters covering at the very most $14 \%$ of global emissions, it is not by itself going to make a significant difference in the fight against climate change. ${ }^{72}$ As for the largest emitters, the United States has only pledged to reduce its emissions by $17 \%$ below 2005 levels, but has never adopted any legally binding agreement at a national level. ${ }^{73}$ Further, the United States stated early on in the Doha negotiations that it would not increase its 17\%-by-2020 target because "the scale and extent of [the United States'] effort ... [is] enormous."74 Similarly, the U.S. Environmental Protection Agency (EPA) has only recently begun developing standards for GHG emissions from stationary and mobile sources, which will have some positive effect 75 but likely not soon enough. ${ }^{76}$ China and India are still claiming a right to emit a significant amount of the total, although not per capita, amount of GHGs in order to develop and modernize. ${ }^{77}$ Finger-pointing, passing the hot potato, and procrastination are still the name of the game at the national and supranational levels and may still be so for some time to come; time that just is not available if we want to avoid what experts fear will be extreme results. ${ }^{78}$ There is thus broad agreement among legal scholars that the international treaty regime and national action is currently not leading to effective progress against climate change. ${ }^{79}$

Since the national and international climate change regimes are at least temporarily, and perhaps permanently,

2013).

72. Ritter, supra note 29.

73. Karl Ritter, UN Climate Boss: No Support for Tough Climate Deal, YAHOO! NEWS (Nov. 30, 2012), http://news.yahoo.com/un-climate-boss-nosupport-tough-climate-deal-123816100.html.

74. US Defends "Enormous" Climate Efforts at UN Talks, CBS NEWS (Nov. 26, 2012), http://www.cbsnews.com/8301-205_162-57554338/u.s-defendsenormous-climate-efforts-at-u.n-talks/.

75. What is EPA Doing About Climate Change?, EPA, http://www.epa.gov/climatechange/EPAactivities.html (last visited Feb. 6, 2013).

76. See supra Part II.A.

77. Peter Singer, A Fair Deal on Climate Change, PRoJeCt SYNDICATE (June 10, 2007), http://www.project-syndicate.org/commentary/a-fair-deal-onclimate-change.

78. See supra Part II.A.

79. See, e.g., Hari M. Osofsky, Is Climate Change "International"? Litigations's Diagonal Regulatory Role, 49 VA. J. INT'L L. 585, 600 (2009) (“The international legal regime suffers from both a lack of political will and the complexities of national implementation."). 
dysfunctional, there is a clear need for action by lower-level structures. Whereas possible solutions at the scaled-up level would add to the picture, they are no longer considered "the only game in town"; 80 in fact, quite far from it. A rapidly growing body of scholarship points to the emergence of a range of sub-state actors who are developing their own initiatives and approaches to climate change action. 81 In one study, for example, more sub-states than actual states were taking climate change initiatives: out of fifty-eight experiments, only nine were nation states. ${ }^{82}$ Localized action is thus overtaking the importance of national and supranational climate change law. The next Part will analyze some such drivers of action.

\section{LOCAL CLIMATE CHANGE EXPERIMENTS}

New actors at both the local government and nongovernmental levels are surfacing and becoming the focus of attention in the climate change field. 83 Because of the established lack of effective action by traditional actors, it is worth examining these non-traditional actors to examine whether they can be considered to be able to produce viable alternatives to more traditional action or whether they just add to an already increasingly fragmented, yet largely ineffective, climate governance system. ${ }^{84}$ For purposes of limitation, the focus of this article will be on action taken by select nonemissions trading programs at the subnational level only. As one of the purposes of this article is to determine if scaled-down action within climate change may already have or promise to take on any legally binding nature where legally binding solutions at the national and supranational levels have largely failed to surface, the main focus of this article will focus on initiatives that voluntarily feature at least some mandatory aspects, broadly interpreted. Thus, the article will analyze

80. Cf. Gremillion, supra note 59, at 1229 (quoting John Gummer) (defending the Kyoto Protocol as the "only game in town").

81. See, e.g., Heike Schroeder \& Harriet Bulkeley, Global Cities and the Governance of Climate Change: What is the Role of Law in Cities?, 36 FORDHAM URB. L.J. 313, 315 (2009).

82. Matthew J. Hoffman, Climate Governance at the Crossroads: EXPERIMENTING WITH A GLOBAL RESPONSE AFTER KYOTO 30-31 (2011).

83. See, e.g., STEINER ANDREsEn \& LARs H. Gulbrandsen, FridtJoF Nansen Inst., The Role of Green NGOs IN Promoting Climate COMPLIANCE (2003), available at http://www.fni.no/doc\&pdf/rapp0403.pdf.

84. See supra Part II.C. 
initiatives that apply "strict" accountability with traditional enforcement, programs with broader forms of accountability but no strict enforcement, and models with reporting requirements and regulatory implications but no enforcement per se. For comparison of possible efficiencies, however, some promising city coalition programs without any enforcement will also be analyzed.

\section{A. EXPERIMENTS With TRADITIONAL ENFORCEMENT METHODS}

The two initiatives analyzed below feature enforcement mechanisms under which actors are held strictly accountable if failing to meet their self-imposed but binding commitments. One experiment employs monetary fines, and the other employs expulsion from group membership for compliance failures. Such enforcement mechanisms more closely resemble traditional forms of compliance securement than some of the newer, collaborative experiments that will be analyzed later.

Because the purpose of this article is to predict the possible future efficacy of non-traditional, local climate change experiments, the article does not critique the chosen degree of severity, or possible lack thereof, of the sanctions chosen by each initiative. The interesting aspects of the actual steps taken are to consider whether they might lead to any effect at all, not whether other types or degrees of sanctioning may be more effective than those chosen. Both the potential for procedural and substantive efficacies will be analyzed.

\section{EU Covenant of Mayors}

Urban activity is associated with " $80 \%$ of energy consumption and $\mathrm{CO}_{2}$ emissions." 85 Against this background, the European Commission launched the Covenant of Mayors (Covenant) in 2008 to endorse and support the efforts deployed by local authorities to reduce their contributions to climate change. ${ }^{86}$ Covenant signatories aim to meet and exceed the EU's target of $20 \% \mathrm{CO}_{2}$ reductions by 2020.87 Some signatories voluntarily go much further than that. For example, the city of Halmstad, Sweden, has adopted a $45 \%$ reduction goal. 88

85. The Covenant of Mayors, COVEnANT MAYORS, http://www. eumayors.eu/about/covenant-of-mayors_en.html (last visited Jan. 25, 2013).

86. $I d$.

87. Id.

88. Municipality of Halmstad, Sustainable Energy ACtion Plan: STRATEGIC DOCUMENT FOR A SUSTAINABLE CONVERSION OF ENERGY IN 
Through these goals, local authorities would contribute as much as one fifth of the total emissions reductions effort needed for the whole EU. 89

The Covenant is open to democratically constituted cities, whatever their stage of implementation of their existing energy and climate policies. ${ }^{90}$ Currently, the Covenant has no less than 4,392 signatories representing over 168 million inhabitants. ${ }^{91}$ Whereas the Covenant was initially open only to cities in Europe, it now offers membership to cities around the world. ${ }^{92}$ Thus, in addition to the many EU members, numerous non-EU local authorities have joined the initiative including cities such as Buenos Aires, Argentina; Lviv, Ukraine; Osh, Kyrgyzstan; Fornelli, Cameroon; and Ushaia, Argentina, the southernmost city in the world. 93

The signatory cities plan to go beyond the objectives set by the EU through the use of individualized Sustainable Energy Action Plans (SEAPs) with follow-up implementation reports, by adapting city structures "in order to undertake necessary actions," by mobilizing civil society to take part in developing the SEAPs, and by sharing "experience and know-how with other territorial units." 94 The action taken must cover at least three of the Covenant's four key sectors: transportation; municipal buildings; tertiary buildings, equipment and facilities; and residential buildings. ${ }^{95}$

If the $\mathrm{CO}_{2}$ reduction objectives set forth in the SEAP are not met, or if an SEAP is not submitted within the year following formal city adoption of the Covenant, the cities will be

HALMSTAD FOR 2010-2014, at 5 (2011), available at http://helpdesk. eumayors.eu/docs/seap/714_1329817723.pdf.

89. Covenant of MaYors, TOWARds A Low CARBon Future 4 (2011) [hereinafter TOWARDS A LOW CARBON FUTURE], available at http://www.eumayors.eu/IMG/pdf/brochure_com_web_FINAL_18_11_2011.pdf.

90. As a Local Authority, COVENANT MAYORS, http://www.eumayors.eu/ participation/as-a-local-authority_en.html (last visited Jan. 25, 2013). If cities are too small to prepare a GHG inventory or draft an action plan, they "should be supported by administrations who can." COVENANT OF MAYORS, COVENANT OF MAYORS 4 (2008), available at http://www.eumayors.eu/IMG/pdf/ covenantofmayors_text_en.pdf.

91. COVENANT MAYORS, http://www.eumayors.eu/index_en.html (last visited Mar. 23, 2013).

92. TOWARDS A LOW CARBON FUTURE, supra note 89, at 9.

93. Id.

94. As a Local Authority, supra note 90, at 2.

95. TOWARDS A LOW CARBON FUTURE, supra note 89, at 5. 
terminated from program membership. 96 "Signatories who fail to fulfill their commitments are temporarily suspended from the initiative until they can prove otherwise. In addition, the actual implementation of the SEAP is ensured by the biannual submission of a monitoring report." 97

What motivates cities to undertake this type of commitment? Public relations are important. The cities are given a perceivably significant opportunity to make a public statement of extra commitments to $\mathrm{CO}_{2}$ reductions and thus to make their territories known as pioneers in climate change reduction efforts. ${ }^{98}$ Shared expertise, as well as the opportunities to benefit from EU endorsement and support, also factor in. ${ }^{99}$ Further, members may also qualify for various types of funding through the initiative. 100

According to the EU Commissioner for Climate, Ms. Connie Hedegaard, more than 2300 local authorities have already gone beyond the 2020 targets before the adopted deadline. 101 This, of course, is significant. It is thus fair to label action at this level substantively successful, at least under the EU Covenant umbrella. It is also procedurally promising in that the program motivates a greater and greater number of local authorities and their private-citizen constituents to take joint action in developing and implementing action plans.

\section{Carbon Rationing Action Groups (CRAGs)}

The CRAG initiative began in England. CRAGs are composed of groups of private individuals who have committed to reducing their individual and collective carbon footprints. ${ }^{102}$ "[T]he core idea behind CRAGs is that personal responsibility is key, and that lobbying the government is only half of the solution." 103 CRAGs have been compared to "Weight-Watchers

96. As a Local Authority, supra note 90, at 2.

97. TOWARDS A LOW CARBON FUTURE, supra note 89, at 5.

98. As a Local Authority, supra note 90.

99. $I d$.

100. $I d$.

101. TOWARDS A LOW CARBON FUTURE, supra note 89, at 3.

102. Sarah Krakoff, Planetarian Identity Formation and the Relocalization of Environmental Law, 64 FLA. L. REV. 87, 115-16 (2012).

103. Jamie Andrews, A Rational Approach to Carbon, Ecologist, Nov. 2008, at 40,40 . 
for the energy-conscious."104 The aims of CRAG schemes are:

1. To make us all aware of our personal $\mathrm{CO}_{2}$ footprint

2. To find out if it can help us make radical cuts in our personal $\mathrm{CO}_{2}$ emissions

3. To help us argue for (or against!) the adoption of similar schemes at a national (DTQ) and/or international (C\&C) [Contraction and Convergence] level

4. To build up solidarity between a growing community of carbon conscious people

5. To share practical lower-carbon-living knowledge and experience ${ }^{105}$

In the United Kingdom (UK), there are as many as twenty active CRAGs with established rules and at least one carbon accounting year underway, as well as eleven start-ups that are still recruiting members or have not yet determined rules or started a carbon accounting year. ${ }^{106}$ In the United States, there are four established CRAGs and two startups. ${ }^{107}$ In Canada, one established CRAG and one startup exist, and China has one established CRAG.108 It should be noted that it is questionable whether all of these experiments are still truly active or not, and if so, what their level of activity is. ${ }^{109} \mathrm{In}$ fact, some CRAG members have expressed doubt about whether their respective CRAGs are still fully functioning. ${ }^{110} \mathrm{Key}$ members are examining strategies "to help the movement grow and continue to flourish." 111 At any rate, the CRAG scheme is worth briefly considering to glean the lessons that were, after all, produced even if the CRAG scheme has since stalled in some instances or to some extent.

A CRAG consists of approximately 250-350 members. ${ }^{112}$ The CRAGs either set an annual emissions target (a ration) in total amounts; for example, five metric tons of $\mathrm{CO}_{2}$ per person or a percentage-based cut in emissions compared to the previous year. ${ }^{113}$ Most British groups with a per capita target

104. Id. at 42 .

105. HowELL, supra note 30 , at 3.

106. Krakoff, supra note 102, at 117.

107. Id.

108. Id.

109. HowELL, supra note 30 , at 4 .

110. Id.

111. Andrews, supra note 103 , at 43.

112. HowELL, supra note 30, at 4.

113. Carbon Equity: What is a Carbon Rationing Group, Climate ACTION CENTER, http://web.archive.org/web/20120618135932/http://climateactioncen 
started with 4500 kilograms, an approximately 10\% per annum reduction of the UK average for direct emissions. ${ }^{114}$ The rationale was that a $10 \%$ per annum reduction is what is needed to cut emissions by $90 \%$ by 2030 , which is the UK's fair share of the global reduction necessary to avoid warming of more than $2^{\circ} \mathrm{C} .115$ Most CRAGs operate with a target that is the same for each member at a certain emissions level; for example, a " $25 \%$ reduction per year for those who start with a footprint of 15-20 tonnes, down to a 5\% reduction for those who start with a footprint of 5 tonnes or lower."116 Some CRAGs have differentiated obligations and some allow members to set their own targets. ${ }^{117}$ Some do not have a fixed ration at all.118 Members keep track of their own emissions by keeping a record of household energy use and private car and plane travel. ${ }^{119}$

The most noteworthy aspect of the CRAG initiative is that many of the groups impose penalties on noncompliant members without government mandates requiring such enforcement.120 This self-imposition of traditional rule enforcement by nongovernmental groups is unique in the climate change framework. ${ }^{121}$ While national and supranational bodies still discuss whether any future schemes should be legally enforceable and, if so, how to implement such enforcement, these groups have already voluntarily taken on mechanisms with quasi-legal ramifications, thus showing a lack of opposition to traditionally styled norm enforcement in the climate change context, at least by some members of civil society. ${ }^{122}$

The predominant design of the CRAG enforcement system is based on financial penalties. ${ }^{123}$ Of the active CRAGs listed in

\footnotetext{
tre.org/carbon-equity (last visited Jan. 28, 2013) [hereinafter Carbon Equity].

114. HOWELL, supra note 30 , at 11.

115. Id.

116. Id. at 10 .

117. See id.

118. Id. at 4 .

119. Carbon Equity, supra note 113.

120. See HowelL, supra note 30, at 1-4; Andrews, supra note 103, at 40; Carbon Equity, supra note 113.

121. See generally Andrews, supra note 103, at 40-43 (describing CRAGs and highlighting their unique structure).

122. See generally Andrews, supra note 103, at 43 ("CRAGs is a practical implementation of a well-researched policy....We are testing it out and seeing how it works in practice." (quoting David Bassendine)).

123. HOWELL, supra note 30, at 13.
} 
one report, fourteen have a financial penalty for exceeding the carbon target, ranging from two pence to ten pence per kilogram. ${ }^{124}$ Many groups cap the penalty at $£ 100$ per year and "[t]wo CRAGs allow over-emitters to do voluntary work in lieu of paying the financial penalty." 125 Seven CRAGs chose not to have a penalty at all. ${ }^{126}$ Only two CRAGs operate a carbon "trading" scheme, "where under-emitters receive payments from over-emitters." 127 Instead, six CRAGS give monies "from over-emitters to carbon reduction projects, environmental charities, or other 'good causes."'128 A few have yet to decide what to do with the penalties paid by the over-emitters, but appear to be considering funding carbon offsetting projects or environmental groups instead of financially rewarding underemitters. ${ }^{129}$ Finally, not all CRAG participants (CRAGers) attribute the changes in their carbon consumption patterns to their involvement with the CRAG scheme. ${ }^{130}$ Although some do not so connect their behavioral patterns to CRAG involvement, the mere fact that they are members of a CRAG has doubtlessly had an effect on their thinking, which is significant too.

The psychology of penalties in the carbon context is relevant to considerations of whether action of this nature and at this level has the potential for being substantively efficient.131 First, many CRAGers did not think that the financial penalty applied had actually changed their carbon consuming behavior, in part because the penalties are too small.132 One person said about a potentially larger penalty: "It would focus my mind. I wouldn't be content to just let things drift and think if it's a little bit I'll pay. I would have to actually sit down and work it out and that would be good."133

The embarrassment factor should also be considered: some people feel embarrassed about receiving money from fellow CRAGers, but not from larger, unknown sources. ${ }^{134}$ Thus, just

124. Id.

125. Id.

126. Id.

127. Id.

128. Id.

129. Id.

130. Id. at 19 .

131. Id. at $5,14-16$.

132. Id. at $14-15$.

133. Id.

134. Id. at 16 . 
over $50 \%$ of the interviewees in one study expressed "qualified to enthusiastic" support for the introduction of a national personal carbon accounting scheme in the UK.135 One of the main reasons for such support is that a national plan would still take the form of a redistributive policy, but one in which the incentive is having to pay money to a large and relatively anonymous entity rather than gaining money from a small group whose members more closely identify with one another. ${ }^{136}$ The embarrassment factor is not perceived as being a barrier in a national scheme because, as one CRAGer stated, "[T]here wouldn't be this 'I'm doing it to you my neighbour' sort of factor." 137

So far, a few CRAGs have been able to create some substantively promising results. Members of some groups reduced their footprints by $27 \%$, from 4.9 tonnes to 3.6 tonnes, just in their first year of membership. 138 The 3.6 metric tons footprint is $31 \%$ below the UK average of 5.2 metric ton for direct carbon emissions. ${ }^{139}$ The average baseline footprint of CRAGers was only "6\% below the UK average." 140 Thus, the members were not already at a significant advantage or disadvantage when starting. ${ }^{141}$

It is important to consider what motivates individuals to comply with mandates that have been imposed on them from the top down or that they have imposed upon themselves in order to attempt to identify the most promising solutions for possible future program emulation. The motivation to observe binding mandates comes in many forms. ${ }^{142}$ Financial and other traditional, adversarial style penalties are just few of several possibly effective drivers. ${ }^{143}$ Equally important are considerations such as: (1) whether the mandates or laws are seen as sound and necessary from both a personal and social point of view, (2) whether they have been adopted with public participation by trustworthy bodies of authority, and (3)

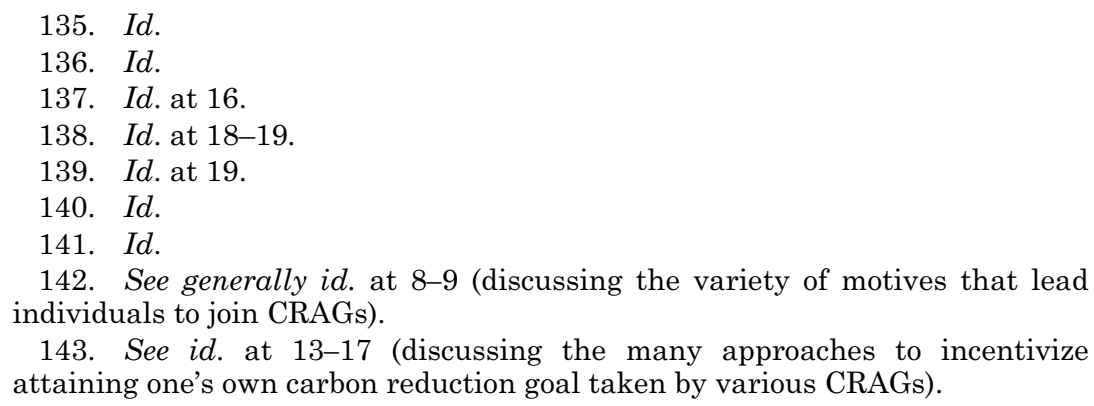


whether they are considered important symbolically as a statement of the direction in which constituents and stakeholders should move. ${ }^{144}$

In the CRAG context, this means that it may actually not be the penalties that motivate members to reduce their carbon emissions. It may just as well be that CRAGers-who by definition are highly environmentally conscious people ${ }^{145}$ believe in the soundness of reducing carbon emissions to begin with, and would thus have been just as or almost just as likely to act even without a financial deterrent. ${ }^{146}$ Although it is difficult to separate just one motivation from a possible multitude of causes leading to any given desired effect, it is still important to monitor whether experiments with strict accountability and penalties for excessive carbon emissions will, over time, lead to more comprehensive and promising patterns of carbon reduction than comparable groups without traditional enforcement mechanisms.

It is also important to remember that it cannot be assumed that the experiences of some CRAGers will expand to the general population as a whole, in the UK, or elsewhere, should a national, compulsory, personal carbon accounting scheme be instigated; CRAGers still only represent a limited segment of the general population. However, their results do suggest some interesting issues to consider. For example, whether fixed carbon rations or targets may prove viable, how carbon accounting should be accomplished, and what type of enforcement methods should be applied to subnational or national rationing initiatives, if any.

In sum, the CRAG model appears relevant to climate change efforts, but only as an addition to broader schemes. This is mainly because doubt exists as to whether these groups are truly active anymore and, if so, whether any significant work is being undertaken under the CRAG umbrella. ${ }^{147}$ If CRAGs

144. For more information on the recognized advantages of public participation, see Dellinger, supra note 1 (manuscript at 21-29).

145. HowELL, supra note 30, at 7 ("In general, the CRAGers interviewed could be informally described (and some did describe themselves) as 'the usual green suspects."').

146. Id. at 7-9 (detailing CRAGers' motivations for involvement-many of which were based in environmentally conscientious ideals).

147. See id. at 4 ("[M] embers of two of [the twenty-four active UK CRAGs] expressed doubt when interviewed about whether their CRAG was still functioning."). 
reappear as active, fully legitimate actors in the climate change arena, it would become relevant to continue attempting to verify whether the members take action because of the model or whether they would have done so anyway for personally convincing reasons. It would also be necessary to follow up on the efficacy of self-imposed penalties on group members.

Whereas action scaled down to the purely individual, voluntary micro-level thus appear to be largely insufficient as a stand-alone model at this point in time, ${ }^{148}$ some important lessons can still be derived from the CRAG initiative. First, clear information, 149 targets, ${ }^{150}$ and intergroup support 151 are a must at this level of action. Second, differentiated responsibilities are needed allowing members to individualize their carbon rationing goals, 152 at least within some parameters and to some extent. Third, flexibility and dynamism are key. ${ }^{153}$ Accordingly, whereas on the one hand carbon reduction targets should be clear, the supervising authorities (whether nongovernmental organizations (NGOs) or government entities) should, on the other hand, consider the benefits of granting participants some leeway in meeting the targets while still upholding clear overall goals to drive the action forward. This is a fine balance to strike, but an important one. Fourth, having sanctions may be more substantively effective than having none. ${ }^{154}$ If sanctions are monetary in nature, payments and transfers of funds should be overseen by bodies of more traditional authority, such as governments or larger, more established groups than smaller NGOs such as CRAGs. This is because of the embarrassment factor mentioned above. ${ }^{155}$ In

148. See id. at 26-28 (discussing the limitations of CRAGs).

149. See id. at 17-18 (highlighting the value of increased information regarding personal emission levels).

150. See id. at 10-11 (showcasing the role of a variety of target-setting methods within CRAGs).

151. See id. at 23-26 (discussing the significance of the group aspect of CRAGs).

152. See generally id. at 35 (highlighting the issue of how much of an allowance to give to households with children as an example of the necessary tailoring of CRAG approaches).

153. Andrews, supra note 103, at 42 ("CRAGs let individuals chose their own path to carbon reduction.... That flexibility is key to the group dynamic." (quoting CRAG member, Guy Shrubsole)).

154. Cf. HowELL, supra note 30, at 13 ("Of the 24 'active' CRAGs listed on the website, 14 definitely have a financial penalty for exceeding the carbon target ....").

155. See supra notes $134-37$ and accompanying text. 
general, the peer pressure factor does appear to instigate action at the scaled-down level. For example, one CRAGer stated:

If one group member feels the need to take a flight for a particular reason others in the group can effectively sanction it by ensuring that the group target is not exceeded. This is an important concept to explore given that climate change affects us all, no matter who is responsible for the carbon being released into the atmosphere. ${ }^{156}$

Last, but not least, bottom-up action is widely considered necessary to successful climate change efforts. 157 By their very nature, CRAGs demonstrate how such action may spring forth at the very bottom of traditional law- and policy-development hierarchies. ${ }^{158}$ This low level of action is not one typically looked to for action and may not yield sufficient substantive progress without the synergic effects that can be obtained through an interface to other larger-scaled areas of action, 159 but procedurally, CRAGs have added value to the environmental discourse. ${ }^{160}$

\section{B. EXPERIMENTING WITH COLLABORATIVE ENFORCEMENT METHODS}

This section analyzes Climate Savers, an initiative with no traditional adversarial-style enforcement mechanisms. ${ }^{161}$ Instead, this initiative features accountability in the form of monitoring and independent verification combined with secondary implementation requirements. 162 This type of enforcement is more collaborative than traditional approaches with more authoritative and, in some cases, even adversarial approaches. ${ }^{163}$ It is also one promoted in and applied in some

\footnotetext{
156. Andrews, supra note 103, at 42 (emphasis added).

157. See Dellinger, supra note 1 (manuscript at 24).

158. See Andrews, supra note 103, at 40.

159. See generally HowELL, supra note 30, at 33.

160. See generally Andrews, supra note 103, at 43 (discussing the current value and potential future of CRAGs).

161. WWF Climate SAVERS, Discover the BENEFITS OF LEADERSHIP WITH WWF Climate SAVERS 5-9 (2012) [hereinafter DISCOVER THE BENEFITS], available at http://assets.worldwildlife.org/publications/461/files/ original/A5_brochure_Climate_Savers_120701.pdf?1348776926.

162. See WWF Climate Savers Companies Cut 100 Million Tonnes of Greenhouse Gases, WWF (May 9, 2012), http://wwf.panda.org/wwf_news/ ?204638/WWF-Climate-Savers-companies-cut-100-million-tonnes-ofgreenhouse-gases [hereinafter WWF Climate Savers Companies].

163. Discover THE BENEFITS, supra note 161, at 5 ("The process begins with a consultation between the prospective member company and an independent technical expert. Together, we explore what it would entail for
} 
environmental treaty contexts such as the Facilitative Branch of the UNFCCC and the United Nations Economic Commission for Europe Aarhus Convention. ${ }^{164}$

Climate Savers is a World Wildlife Fund (WWF)-run platform for corporations wishing to undertake voluntary sector-leading targets regarding their own GHG emissions as well as to cooperate with other companies in the implementation of innovative solutions for a low carbon economy. ${ }^{165}$ Climate Savers started as a two-year experiment meant mainly to be an advocacy tool, but is now "one of the most ambitious and credible climate business engagement programmes in the world." 166 Members include established corporate giants such as Nike, Johnson \& Johnson, IBM, Novo Nordisk, and Sony. ${ }^{167}$

The members set their own reductions goals tailored to the specific circumstances and operating sector of each member company. ${ }^{168}$ The goals are set in absolute terms for defined timeframes. ${ }^{169}$ Climate Savers writes a memorandum of understanding (MOU) for the participants, who commit themselves in writing to an action plan. ${ }^{170}$ If that plan cannot be implemented, a secondary action plan will be drafted. ${ }^{171}$ The program uses what is known as "stretch targets," under which companies undertake reductions goals that go a few percentages further than that with which the companies are comfortable. ${ }^{172}$ This is done in order to challenge the companies to not just meet, but to exceed even their own expectations and comfort levels. ${ }^{173}$ The MOU is written by the WWF and stipulates that Climate Savers will issue a public statement about the compliance challenges and an action plan to remedy any gaps that may arise. ${ }^{174}$ Compliance review is conducted by

\footnotetext{
your company to be sector-leading in carbon efficiency and how your company can go beyond its existing or previously planned emission reduction targets.").

164. See Dellinger, supra note 1 (manuscript at 45-46).

165. DISCOVER THE BENEFITS, supra note 161, at 3.

166. Id. at 5; Telephone Interview with Matthew Banks, Senior Program Officer, Climate Change, WWF US (June 27, 2012).

167. DISCOVER THE BENEFITS, supra note 161, at 11.

168. Id. at 5 .

169. Id. at 5 .

170. Telephone Interview with Matthew Banks, supra note 166.

171. Id.

172. Id.

173. Id.

174. Email from Matthew Banks, Senior Program Officer, Climate Change,
} 
the independent third party Ecofys. 175

The goals are publicly communicated and will result in pressure to comply from the global community. ${ }^{176}$ Among other things, the companies have to report progress every year at a global summit in front of their peers, adding pressure to comply. ${ }^{177}$ The members' relationship with Climate Savers is, however, non-adversarial and there are no penalties for noncompliance. ${ }^{178}$ This type of oversight and public awareness is thus not unlike the "naming and shaming" enforcement method already known in international law contexts, although typically one that is used against nation states, not private actors as here. ${ }^{179}$

What drives the participants to undertake relatively farreaching goals such as those under the Climate Savers program even without government requirements? A noteworthy aspect of this program is that the commonly perceived public relations advantage of being seen as "green" does not motivate all companies to act. According to Senior Program Officer Matthew Banks, the members participate mainly out of a sense of obligation. ${ }^{180}$ They do not want to be associated with the negative tenets of environmentalism such as the BP and "greenwashing" scandals of recent years. ${ }^{181}$ This counters the otherwise common criticism that companies are more interested in the public relations advantages to be derived from carbon reduction efforts than in any substantive results. This may well be the case for some, but as shown, it does not hold true for all. Among other motivational factors are strong and positive brand images, increased networking opportunities, improved business performance through energy savings, and

WWF US, to Myanna Dellinger, Assistant Professor of Law, W. State Coll. of Law (June 27, 2012) (on file with author); Email from Matthew Banks, Senior Program Officer, Climate Change, WWF US, to Myanna Dellinger, Assistant Professor of Law, W. State Coll. of Law (Dec. 14, 2012) (on file with author).

175. WWF Climate Savers Companies, supra note 162.

176. Telephone Interview with Matthew Banks, supra note 166.

177. Email from Matthew Banks, supra note 174.

178. Telephone Interview with Matthew Banks, supra note 166.

179. Jacqueline H.R. DeMeritt, International Organizations and Government Killings: Does Naming and Shaming Save Lives?, 38 INT'L INTERACTIONS 1, 2 (2012) (defining naming and shaming as "policy of punishment by publicity").

180. Telephone Interview with Matthew Banks, supra note 166.

181. Id. 
improved risk management through reduced energy dependence. ${ }^{182}$ These companies also recognize that "cutting carbon emissions and spurring economic growth can go hand in hand."183 Further, the program acts as a "sounding board, providing valuable guidance for companies seeking to substantially reduce their carbon footprints while growing their businesses and enhancing their brand equity."184

The collaborative enforcement methodology of the program can also be measured against notions of corporate social responsibility, pursuant to which some companies just might act because it is the "right" thing to do. ${ }^{185}$ In this context, carbon reduction action is undoubtedly not only taken for the sake of acting in what is modernly perceived to be environmentally sound ways, but also driven by interests in reducing energy consumption to save money. This is partly because corporations realize that government regulations are inevitable in the long run anyway, and for fears of potential government or shareholder lawsuits for failure to act reasonably in an area in which the law is undergoing change in directions that are not yet fully predictable. One stakeholder said, "It doesn't actually matter whether a board believes in climate change, 'cos [sic] climate change believes in them and they have no choice but to ensure that they are seen to be taking effective action on climate change."186 Thus, whereas some corporations claim that they are not taking action because of any perceived public relations advantages, it is clear that for others, the perceived negative implications of noncompliance is a factor in program compliance.

It is fair to describe Climate Savers as a success. By May 2012, member companies have cut 100 million tonnes of GHGs in direct and indirect emissions, which corresponds to twice the current annual emissions of Switzerland. ${ }^{187}$ One example of effects reached through the program is Johnson \& Johnson. This company's "climate change goal was to reduce its baseline

182. Discover THE BENEFITS, supra note 161, at 6-7.

183. Id. at 3 .

184. Id.

185. For more information about why civil society observes norms that are considered morally sound, although perhaps not mandated by positive law, see Dellinger, supra note 1 (manuscript at 4-8).

186. Heike Schroeder \& Harriet Bulkeley, Global Cities and the Governance of Climate Change: What is the Role of Law in Cities?, 36 FORDHAM URB. L.J. 313, 340-41 (2009).

187. WWF Climate Savers Companies, supra note 162. 
$1990 \mathrm{CO}_{2}$ emission levels [for its facilities] by 7 percent by the end of 2010."188 When that target was initially adopted, the company considered it very hard to reach. Nonetheless, the company not only achieved, but exceeded the goal by achieving a $23 \%$ reduction at the end of 2010. ${ }^{189}$ Simultaneously, the company experienced a sales growth of approximately $450 \% .190$ At the end of 2011, Johnson \& Johnson realized a more modest $4.9 \%$ reduction in $\mathrm{CO}_{2}$ emissions while still realizing a $5.5 \%$ increase in sales. 191 In regards to its transportation-related emissions, the company has announced two related goals: a five-year goal of reducing the $\mathrm{CO}_{2}$ emissions to 142 grams/kilometer per vehicle, which it is on track to achieve, ${ }^{192}$ and to realize a $20 \%$ improvement in its overall fleet emissions efficiency for its global inventory of over 28,000 vehicles. ${ }^{193}$ For its overall energy use, however, the company states only that it "will continue to follow The Greenhouse Gas Protocol issued by the World Business Council for Sustainable Development and the World Resources Institute" whose goals are not transparent.194 Other companies, although not members of Climate Savers, have also managed to reduce energy consumption in tough financial times (perhaps precisely because of such times). As two examples, "Dow Chemical has decreased its energy costs $\$ 9$ billion since 1994,"195 and "Walmart has increased the fuel efficiency of its distribution fleet by $69 \%$ since 2005." 196 There is thus reason for cautious optimism that some companies will proactively and voluntarily seek to reduce their emissions without traditional legal requirements.

188. JOHNSON \& JOHNSON, 2011 RESPONSIBILITY REPORT 29 (2011), available at http://www.jnj.com/wps/wcm/connect/e265d6804bc83ae392f6ffbf 30c50c56 /2011-responsibilty-report.pdf?MOD=AJPERES.

189. $I d$.

190. Id.

191. Id.

192. Id. at 31 .

193. Id. at 30 .

194. Id. at 29. The emission reduction goals of this program are not clear, which casts some doubt on the ultimate willingness of the participating corporate members in taking effective action and not just reiterating more or less empty rhetoric. See About the GHG Protocol, GREenHOUSE GAS PROTOCOL, http://www.ghgprotocol.org/about-ghgp (last visited Feb. 13, 2013) (describing the GHG Protocol).

195. Winston, supra note 3.

196. Id. 
The Climate Savers initiative shows several important aspects of non-governmental action against climate change under the auspices of an established, reputable organization. First, strict oversight by a third party of claims of environmental advances by corporations is needed to avoid "greenwashing" or the appearances thereof. Of course, it is impossible to prevent companies from producing selfinterested, yet largely untrue promotional statements to boost their image and sales. ${ }^{197}$ It is precisely for this reason that membership of and accountability through organizations such as Climate Savers is an advantage both to those companies that actually intend to take relevant action and to the outside world. Strict or traditional enforcement of organizational goals may actually not be needed to ensure goal compliance; softer oversight methods with assistance in reaching the adopted goals may be equally effective. Considerations of public relations are still key in this context as shown both by the interest of some in being seen as part of the green movement and, similarly but for the opposite reason, the interest of some in not being associated with that movement because of recent perceived, although arguably not always factually correct, scandals rocking the environmental movement.

Of course, the most important issue in the corporate context is not so much whether some companies actually mean well and truly intend to reduce their carbon footprints, whether for purely financial or for more altruistic reasons, but that the traditional carbon industry is still able to counteract much of the carbon reductions achieved by other companies through the sheer size of the industry's planned carbon output as described above. 198 The carbon industry is virtually out of government control at the global level. This situation is untenable and must be turned around if we as a world society are truly serious about finding solutions to climate change. ${ }^{199}$ It is beyond the scope of this article and almost impossible to answer the question of just how to do so. However, it is still encouraging that initiatives such as Climate Savers are able to work

197. For example, in 2012, BP ran commercials on national televised news stations still boasting the company's alleged interest in the environment years after having caused one of the worst oil drilling disasters in history. See Cain Burdeau, BP Ad Campaign Following Gulf Oil Spill Deemed 'Propaganda' by Some, HUFFINGTON POST (Jan. 8, 2012, 11:38 AM), http://www.huffingtonpost .com/2012/01/08/bp-ad-campaign-gulf-oil-_n_1192600.html.

198. See supra Part II.B.

199. See supra Part II.A. 
productively with other corporations if not the carbon industry for obvious reasons. In short, action on many fronts is required. It is fair to conclude that Climate Savers sets a promising precedent for companies willing to undertake voluntary, but quasi-binding action.

\section{VOLUNTARY EXPERIMENTS}

The U.S. Conference of Mayors Climate Protection Agreement (MCPA) and the International Council for Local Environmental Initiatives's (ICLEI) GreenClimateCities initative create contrast to programs with a more binding nature such as the EU Covenant of Mayors. These two voluntary programs are, in particular, relevant in this context as both they and the Covenant are city coalition programs. But whereas the Covenant appears to be both procedurally and substantively successful, 200 more action needs to be demonstrated by the MCPA and GreenClimateCities before these can reasonably be determined to be effective in both aspects as well.

\section{MCPA}

The MCPA has been ratified by 1,054 mayors from cities in all 50 states, the District of Columbia, and Puerto Rico, representing a total population of almost 90 million people. ${ }^{201}$ The program was launched by then Seattle Mayor Greg Nichols in 2005 on the date on which the Kyoto Protocol took legal effect for the ratifying nations. ${ }^{202}$

Under the MCPA, participating cities have committed to take the following three actions:

- Strive to meet or beat the [2012] Kyoto Protocol targets in their own

communities, through actions ranging from anti-sprawl land-use

200. See supra Part III.A.1.

201. List of Participating Mayors, Mayors Climate Protection Center, http://www.usmayors.org/climateprotection/list.asp (last visited Feb. 13, 2013). However, a map of participating cities show significant clustering around traditionally progressive urban areas such as San Francisco, Seattle, Portland, and other large metropolitan areas. Cities That Have Signed On, MAYORS CLIMATE PROTECTION CENTER, http://www.usmayors.org/climateprotection/ ClimateChange.asp (last updated Feb. 12, 2013).

202. U.S. Conference of Mayors Climate Protection Agreement, MAYORS Climate PROTECTION CENTER, http://www.usmayors.org/climateprotection/ agreement.htm (last visited Mar. 24, 2012). 
policies to urban forest restoration projects to public information campaigns;

- Urge their state governments, and the federal government, to enact policies and programs to meet or beat the greenhouse gas emission reduction target suggested for the United States in the Kyoto Protocol --[a] 7\% reduction from 1990 levels by 2012 ; and

- Urge the U.S. Congress to pass the [sic] bipartisan greenhouse gas reduction legislation, which would establish a national emission trading system 203

Although the initiative thus refers to "commitments," it features no enforcement mechanisms and thus no ramifications for noncompliance. ${ }^{204}$ The program is entirely voluntary. ${ }^{205}$

To sign up for the MCPA, mayors have to sign a simple one-page "agreement" simply stating, "You have my support for the Mayors Climate Protection Agreement" with the possibility for adding comments that will be posted on the website. ${ }^{206}$ Although simplicity in drafting agreements can be good, too much simplicity can also be seen as a lack of a genuine interest in reaching the ultimate goal, namely GHG emissions reductions that can prevent dangerous climate change. Further, because the $7 \%$ target to be reached is substantively highly limited, especially as knowledge has cemented in recent years that reductions need to be tenfold that of the initial MCPA "commitment," the MCPA's outcome-relevance has dwindled in spite of at least some early promise for potential. ${ }^{207}$ This is arguably aggravated by the fact that the agreement features no enforcement or apparent accountability. ${ }^{208}$ Today, the MCPA thus appears to have become more of a political public relations tool than an agreement with much real "bite." 209

203. Id. (emphasis added).

204. Telephone Interview with Kevin McCarty, Managing Dir., MCPA (Aug. 7, 2012).

205. Id.

206. The U.S. Conference of Mayors Climate Protection AgreementSignature Page, USMAYORS.ORG, http://www.usmayors.org/climateprotection/ documents/signaturepage.pdf (last visited Apr. 24, 2013).

207. See supra Part II.A.

208. Cf. U.S. Conference of Mayors Climate Protection Agreement, supra note 202.

209. Compare supra text accompanying note 203 (explaining the goals of the MCPA), with supra Part II.A (noting necessary emissions reductions). It should be kept in mind that emissions reductions of approximately $5 \%$ was the goal discussed under the UNFCCC regime at the time the MCPA was adopted. See Kyoto Protocol to the United Nations Framework Convention on Climate Change, art. 3, Dec. 11, 1997, 2303 U.N.T.S. 162. However, it soon became 
Although the participating mayors have "recognize[d] the need for a federal partner in this effort [and] they cannot and will not wait to act until Washington is ready to move on this problem," the MCPA website does not provide any updates as to any substantively significant results or even any recent general updates. ${ }^{210}$ Although it is difficult to prove a negative, one is inclined to assume that if the organization's members had been able to meet or exceed their targets, such results would have been announced through the program, especially given the initial interest by the members in the potential for public relations benefits via the MCPA.

\section{ICLEI and the GreenClimateCities Initiative}

ICLEI-Local Governments for Sustainability-counts among its members " 12 mega-cities, 100 super-cities and urban regions, 450 large cities as well as 450 medium-sized cities and towns in 84 countries." 211 ICLEI was the first global network of cities and local governments established to achieve sustainability at the local level. ${ }^{212}$ ICLEI's 1991 "Urban $\mathrm{CO}_{2}$ Reduction Project[] implemented in 14 cities across the U[nited] S[tates], Europe and Canada, was [among] the first concrete measure[s] in local climate action." 213 Under ICLEI's initial Cities for Climate Protection (CCP) campaign, participating cities were expected to follow a "five milestone" process following a political commitment by their local governments. ${ }^{214}$ Milestone One requires the cities to "[c]onduct a baseline emissions inventory and forecast." 215 Milestone Two calls for the "[a]dopt[ion of] an emissions reduction target for the forecast year." 216 Milestone Three specifies the requirements

clear that much higher emissions reductions goals were needed. See supra Part II.A. The MCPA has not changed its targets in line with this.

210. About the Mayors Climate Protection Center, MaYors Climate PROTECTION CENTER, http://www.usmayors.org/climateprotection/about.htm (last visited Feb. 13, 2013).

211. Who We Are, ICLEI GLOBAL, http://www.iclei.org/iclei-global/who-isiclei.html (last visited Mar. 24, 2013).

212. ICLEI Climate Program, ICLEI GLOBAL, http://archive.iclei.org/ ?id=940940 (last visited Mar. 24, 2013).

213. Id.

214. The Five Milestone Process, ICLEI GLOBAL, http://www.iclei.org/ index.php?id=810 (last visited Jan. 27, 2013).

215. Id.

216. Id. 
for the development of a local action plan:

Through a multi-stakeholder process, the city develops a Local Action Plan that describes the policies and measures that the local government will take to reduce greenhouse gas emissions and achieve its emissions reduction target.... In addition to direct greenhouse gas reduction measures, most plans also incorporate public awareness and education efforts. ${ }^{217}$

Milestone Four addresses the "[i]mplement[ation of] policies and measures."218 Milestone Five requires the cities to monitor and verify their respective progress on the implementation of measures. ${ }^{219}$

GreenClimateCities is ICLEI's newest EU-funded platform for low-carbon city development which is meant to phase out the CCP campaign. 220 The program launched in June 2012 and is being rolled out through pilot implementation in India, South Africa, Indonesia, and Brazil. ${ }^{221}$ The program assists cities in achieving low-carbon development and management through, among other methods, technical support, networking, carbon target-setting, emissions accounting and control, and the quantification of reduction measures:222

Cities will receive guidance and technical support from ICLEI as they set up their greenhouse gas emissions inventory; identify opportunities for rapid emission reductions; develop a climate action plan; identify finance for urban infrastructure projects; and measure progress and report their achievements to the global carbonn Cities Climate Registry. This 3-step approach of analyzation, action and acceleration ensures continuation of best practices and tailors them to the specific urban area. ${ }^{223}$

217. $I d$.

218. $I d$.

219. Id.

220. See Low-Carbon, Climate-Resilient Cities, ICLEI GLOBAL, http://www.iclei.org/index.php?id=800 (last visited Jan. 27, 2013) (noting that local climate initiatives are only one part of a larger concept of low emission urban development).

221. Email from Yunus Arikan, Manager, ICLEI, to to Myanna Dellinger, Assistant Professor of Law, W. State Coll. of Law (Nov. 21, 2012) (on file with author).

222. See id.; GREENClimAteCITIES, ICLEI 1-3 (2012), available at http://www.iclei.org/fileadmin/user_upload/documents/Global/About_ICLEI/br ochures/GCC_final_Brochure.pdf (highlighting the HEAT+ accounting and reporting tool); Low-Carbon, Climate-Resilient Cities, supra note 220 (explaining the technical support and networking components).

223. GreenClimateCities: Local Governments Respond to Green Cross Task Force's Appeal for Urgent Action on Climate Change, ICLEI (June 18, 2012), http://archive.iclei.org/index.php?id=1487\&tx_ttnews[pS] $=1357901598 \& t x \_t t n$ ews[pointer] $=9 \&$ tx_ttnews[tt_news] $=4873 \&$ tx_ttnews[backPid] $=1556 \& \mathrm{cHash}=$ 19a23eca88 [hereinafter Local Governments Respond]. 
Members of the GreenClimateCities set specific and individual carbon reduction goals. ${ }^{224}$ These members' individual goals are measured using Heat+, ICLEI's globally accessible online accounting and reporting tool sponsored by, among others, the EU.225 Results are registered with the carbon $n$ Cities Climate Registry (cCCR), which is overseen by the neutral third party Bonn Center for Local Climate Action and Reporting. ${ }^{226}$ As of November 2012, 232 cities from 25 countries, purported to represent a population of 235 million inhabitants and control community GHG emissions of 1.5 $\mathrm{GtCO}_{2}$ each year, reported 561 climate and energy commitments, 557 GHG inventories, and a total of 2092 mitigation and adaptation actions and action plans through the cCCR. 227

Importantly, global partnering with other climate change projects such as the WWF Earth Hour City Challenge, the Japan Registry Project, and The Mexico City Pact forms a significant part of ICLEI's efforts, just as the initiative operates with an interface to major supranational governmental organizations. ${ }^{228}$ For example, Heat+ complies with the IPCC guidelines just as ICLEI partners with the United Nations Environmental Programme. ${ }^{229}$

Although ICLEI, and thus GreenClimateCities, asks the members to commit to certain targets, it does not apply any enforcement method, at least not in a traditional sense of the word. ${ }^{230}$ Instead, the members are expected to self-police their

224. See, e.g., GreenClimateCities, supra note 222, at 1, 3 (noting the entry point may be different for "starters and advanced cities"); Low-Carbon, Climate-Resilient Cities, supra note 220 (stating the availability of local tools for setting local goals).

225. See Low-Carbon, Climate-Resilient Cities, supra note 220 (highlighting the availability of the HEAT+ system); Sponsors, HEAT+, http://heat.iclei.org/heatplusv4n/sponsors.aspx (last visited Jan. 27, 2013) (listing the organizations that support HEAT+).

226. GREENCLIMATECITIES, supra note 222 , at 4 .

227. CARBonN Cities Climate Registry, Raising the Global Level of AMBition THROUGH LOCAL ClimATE ACTION 1 (2012), available at http://citiesclimateregistry.org/fileadmin/user_upload/cCCR/cCCR_November2 012_Update/cCCR_November2012.pdf.

228. Id. at 6 .

229. See GREenClimateCities, supra note 222, at 3; Our Partners, ICLEI, http://www.iclei.org/cn/iclei-global/our-partners.html (last visited Mar. 24, 2013).

230. See Local Governments Respond, supra note 223 ("[I]nvites cities worldwide ... to take voluntary climate action now ....”). 
efforts and make the outcomes publicly available via the cCCR.231 Thus, members are faced with only the "threat" of potential public scorn if they do not live up to the adopted targets; as an enforcement mechanism, GreenClimateCities finds itself on the voluntary end of the compliance continuum spectrum. ${ }^{232}$ The organization recognizes this fact: "The GreenClimateCities initiative invites cities worldwide to join efforts by local governments from all parts of the world to take voluntary climate action now and not wait for national governments to eventually come to a global climate agreement."233

Whether this model proves to be more or less effective than city initiatives with a more traditional "adversarial" enforcement style, such as that employed by the Covenant, remains to be seen. This program is too new to demonstrate any substantive success. ${ }^{234}$ However, this and similar programs do demonstrate the potential for, and continued interest in, voluntary city action leading to climate change mitigation and adaptation results. ${ }^{235}$ What appears promising from such schemes is the ability for cities around the world to bypass potential state and national government inaction while maintaining an interface to, and potentially cooperating with, supranational organizations. 236 These relatively new actors actually act, whereas traditional actors continue the stalemate situation with which the world community has grown increasingly dissatisfied. ${ }^{237}$ It is precisely because some of these scaled-down initiatives are so new, yet showing progress, that there is reason for cautious optimism that dawn is coming to climate change efforts that go beyond mere rhetoric. ${ }^{238}$ Local entities are adopting emissions targets with, broadly interpreted, some accountability and repercussions for non-

231. See id.

232. Id. (mentioning ICLEI's nineteen-year experience overseeing the voluntary participation in its various programs).

233. Id. (emphasis added).

234. The program started in June 2012 and it takes time for emissions to be reduced and reported. See supra notes 216, 221 and accompanying text.

235. See supra notes 80-82 and accompanying text.

236. See supra note 233 and accompanying text.

237. See Dellinger, supra note 1 (manuscript at 20-22) (highlighting the difficulty inherent in different nations agreeing to climate change initiatives because of competing interests).

238. See supra Part III.A.1-2 (discussing the success of the Covenant and CRAG programs, respectively). 
compliance through a variety of voluntary and mandatory enforcement efforts. At the more voluntary end of the spectrum there are threats of negative publicity and calls for selfcorrection. ${ }^{239}$ At the more mandatory end there are fines, program expulsions, and other more traditional enforcement mechanisms. ${ }^{240}$

\section{INTERIM LESSONS LEARNED FROM CITY COALITION PROGRAMS}

By contrasting the above city coalition initiatives, the following lessons about the potential efficacy of such programs emerge: seen from a more or less isolated point of view, city programs with at least some degree of enforcement appear to be more effective than initiatives without any enforcement. ${ }^{241}$ The type of sanction under the EU program-exclusion from group membership - is arguably not terribly severe at first blush, but may nonetheless drive members to attempt to meet their adopted goals for "naming and shaming" and other reasons. ${ }^{242}$ Public disclosure of progress by each participating entity under the Climate Savers program and the ICLEI-based models, for example, has the same effects and thus demonstrates what the program leaders themselves have determined will help drive cities to join the initiatives and take action. ${ }^{243}$ Listening to the actors themselves is also important to external discourse regarding potential program efficacies. ${ }^{244}$ For example, all programs operate with a significant degree of generalized peer pressure and the desire to stand out as progressive leaders in

239. See, e.g., supra text accompanying notes 176-78 (using reporting in front of peers as its enforcement mechanism).

240. See supra text accompanying notes 96-97, 123-29 (identifying termination from the EU Covenant of Mayors program and fines in the CRAG programs as the enforcement mechanisms, respectively).

241. The MCPA program employs no enforcement mechanism and has shown little success compared to the EU Covenant of Mayors program, CRAG programs, and the Climate Savers program. Compare supra text accompanying note 205, with supra text accompanying notes 101, 138-40, 187-96 (sharing the success of the EU Covenant of Mayors program, CRAG programs, and the Climate Savers program, respectively).

242. See supra Part III.A.1.

243. See supra notes 176-78, 230-33 and accompanying text (Climate Savers and ICLEI, respectively).

244. In some of the programs, sharing experiences and knowledge is a key component in the program. See, e.g., Low-Carbon, Climate-Resilient Cities, supra note 220 (explaining the networking components). 
the climate change arena.245 They are based on both financial stressors and motivators such as financing assistance, difficult economic times requiring cross-sector energy savings, and the realization of the danger of relying on imported oil from politically unstable regions. ${ }^{246}$ Program signatories also wish to benefit from the channeling of funds from competing areas to their local areas.247 Sharing technical and non-technical knowledge among program members and national governance bodies is also important, just as general networking advantages are typically listed among the benefits of joining the programs. ${ }^{248}$

Another lesson pertains to the stronger bargaining position of large (as compared to smaller) governmental units. Thus, actors in the EU city scheme have recognized the benefit of having the EU negotiate with third-party financial actors to set up financial facilities aimed at aiding accomplishment of the tasks of the action plans. ${ }^{249}$ Thus, vertical governance cooperation is important in relation to the success of action initiated by cities and other types of bottom-up action. ${ }^{250}$ Also important is the involvement of civil society. ${ }^{251}$ The MCPA, however, makes no references to any kind of public participation: "Aside from a provision providing for helping with climate change education, no reference is made to the importance and role of an ample public consultation process." 252

245. For example, Mr. McCarty of the MCPA says that after the Seattle mayor took the initiative for the program, the duty became viral in the United States, even at an early point in time. Telephone Interview with Kevin McCarty, supra note 204. According to Mr. McCarty, mayors are aware of the fact that they are often expected to act on socio-cultural changes without initial impetus or support by larger government bodies. Id.

246. Id.; As a Local Authority, supra note 90.

247. Telephone Interview with Kevin McCarty, supra note 204; As a Local Authority, supra note 90.

248. See, e.g., Low-Carbon, Climate-Resilient Cities, supra note 220 (explaining the technical support and networking components of the program).

249. See TOWARDS A LOW CARBON FUTURE, supra note 90, at 6 (highlighting the European Local Energy Assistance facility and the European Energy Efficiency Fund).

250. Id. at 4 (stating that the covenant coordinators play an important role in communicating between the local authorities and the larger national and supranational entities).

251. For the advantages of civil society involvement in bottom-up lawmaking, see Dellinger, supra note 1 (manuscript at 21-28).

252. Rômulo Silveira da Rocha Sampaio, Regulating Climate Change Risk at the Local Level-the Denver Experience: Greenprint or Greenwash?, 17 Mo. ENVTL. L. \& POL'Y REV. 356, 370 (2010). 
Opening up the policy-making process to public participation, including discussing how to proceed on certain issues and how the available financial and other resources should be used, increases the legitimacy of the regulating process and shares responsibilities of the final outcomes. ${ }^{253}$ Then the regulated can become the regulators; a recognized advantage in modern law and policymaking and enforcement. ${ }^{254}$ The EU model's focus on mobilizing civil society to take part in developing the Action Plan is, thus, a better solution and should be emulated in similar future programs.

It is clear that the time has come for cities and other local governance units to step up their action and roles within climate change mitigation and adaptation in more diverse ways than before. Cities enjoy unique positions as advisors, motivators, and role models. ${ }^{255}$ They can lead by example by reducing their own energy consumption in public buildings as well as by procuring their energy from sustainable sources. ${ }^{256}$ They can lead more awareness-raising activities. ${ }^{257}$ As planners, regulators, and developers, they can take relevant legislative and other legal action. ${ }^{258}$ As energy producers and suppliers, they can promote and produce more renewable energy. ${ }^{259}$ In the American context, had a national climate change framework been adopted in the United States, it would have, to a large extent, needed to be implemented at the city level. ${ }^{260}$ Cities and other local government units must be even more proactive and not wait for national governments to lead the way with climate change initiatives. As the above shows, effective action can, and should be instigated at the local level at this point in time. All such solutions will require accurate

\footnotetext{
253. $I d$.

254. See Dellinger, supra note 1 (manuscript at 25).

255. For an analysis of the several roles played by cities as well as their importance to top-down or bottom-up governance, see Dellinger, supra note 1 (manuscript at 21-28). See also TOWARDS A LOW CARBON FUTURE, supra note 90 , at 4 ("[T] he local administration is the closest government level to engage citizens and reconcile public and private interests.").

256. See Dellinger, supra note 1 (manuscript at 56-77).

257. $I d$.

258. $I d$.

259. Id.

260. Cf. TOWARDS A LOW CARBON FUTURE, supra note 90, at 4 (noting that successful cooperative solutions are being achieved at the local and regional levels even when the national and international levels are struggling to implement a successful program).
} 
and reliable emissions accounting and reporting. This aspect will be examined next.

\section{E. REPORTING WITH MANDATORY IMPLICATIONS}

To be considered reliable among climate regulation skeptics and advocates alike, it is particularly important for programs to ensure neutral and reliable reporting, accounting, and compliance oversight. ${ }^{261}$ Consumer demand for transparency with respect to environmental performance is increasing, which further adds to the need for trustworthy reporting programs. ${ }^{262}$ With the establishment of more and more climate-focused initiatives around the world, it is also necessary to apply relatively homogenous and transparent emissions reporting standards such that it is possible to be able to compare "apples to apples" at the international level. ${ }^{263}$ This section will analyze the Climate Registry as an example of how to accomplish these goals and the relevant concerns in future developments of this and other reporting platforms.

A self-proclaimed "bottom-up" approach to emissions accounting, the Climate Registry is a non-profit collaboration established and governed by North American states, provinces, territories, and Native Sovereign Nations. ${ }^{264}$ It is the only program of its kind in North America that started and operates as a voluntary initiative. 265 The program sets standards for members to calculate, verify, and publicly report their GHG emissions into one single registry. ${ }^{266}$ The results are verified by independent bodies accredited by the American National Standards Institute. ${ }^{267}$ The Climate Registry now supports voluntary, regulatory, and mandatory reporting programs and

261. See HofFman, supra note 82, at 89 (belonging to the Climate Register can legitimize reduction claims).

262. Cf. id. at 89, 91 (standardizing reporting measurements allows the public to assess the progress and compare various entities).

263. See id. (using uniform measurements allows all members, whether they are regulated or non-regulated, to assess their progress equally).

264. FAQs, CLIMATE REGISTRY, http://www.theclimateregistry.org/about/ faqs/ (last visited Jan. 27, 2013).

265. Denise Sheehan \& Alex Carr, The Future of GHG Reporting: Patchwork or Tapestry?, EM, Oct. 2010, at 12, 12-14.

266. Mission, CLIMATE REGISTRY, http://www.theclimateregistry.org/about/ mission/ (last visited Mar. 24, 2013).

267. See FAQs, supra note 264 (acknowledging that the verifiers have experience in other areas of verification as well); List of Verification Bodies, CLIMATE REGISTRY, http://www.theclimateregistry.org/resources/verification/ list-of-verification-bodies/ (last visited Jan. 27, 2013). 
thus has both indirect, but also direct, legal implications. ${ }^{268}$

The membership consists of corporations, government agencies (now at the city, state, and federal levels), as well as nonprofit organizations. ${ }^{269}$ The Registry has approximately 430 current members including energy-producing and energysource companies, car manufacturers, mining companies, environmentally-oriented NGOs, colleges, and government bodies. ${ }^{270}$ The Registry partners with several GHG reductions programs such as ICLEI and the U.S. Conference of Mayors' Climate Initiative. ${ }^{271}$ Membership is also required for members of the Western Climate Initiative. ${ }^{272}$ The EPA has, since 2009, required reporting by "large" GHG emitters in the United States. ${ }^{273}$ This reporting, however, must be done directly to the EPA and thus not, for example, to the Climate Registry. ${ }^{274}$ This may add to the "patchwork problem" whereby too many actors on the climate change scene may add unnecessary complexity and overlapping requirements. 275 Because of the sheer extent of EPA's reporting requirement, ${ }^{276}$ it may be feared that this would drive programs, such as the Climate Registry, into a

268. See FAQs, supra note 264 (explaining that while the Registry itself will not establish any regulations, it supports the reporting of any type of emissions data, including those that may also be recorded in order to comply with a law).

269. List of Members, CLIMATE REGISTRY, http://www.theclimateregistry .org/members/ (last visited Jan. 27, 2013).

270. Id.

271. See FAQs, supra note 264 (expressing that the Registry is meant to be complementary to these other programs).

272. HOFFMAN, supra note 82 , at 89 (explaining that the reporting system used by the Climate Registry provided federal regulators with a working model).

273. Consolidated Appropriations Act, Pub. L. No. 110-161, 121 Stat 1844 (2007). According to the EPA, the Greenhouse Gas Reporting Program "will help us better understand where greenhouse gas emissions are coming from and will improve our ability to make informed policy, business, and regulatory decisions." Greenhouse Gas Reporting Program, EPA, http://www.epa.gov/ ghgreporting/index.html (last visited Jan. 29, 2013).

274. Cf. Greenhouse Gas Reporting Program, supra note 273 (indicating that all GHG data must be reported using the EPA's GHG Reporting Program).

275. See Dellinger, supra note 1 (manuscript at 22) (stating that bottom-up lawmaking can be "unchoreographed"); Sheehan \& Carr, supra note 265, at 12.

276. The "EPA estimates [that the reporting rule] will cover approximately $85 \%$ of U.S. GHG emissions and apply to 10,000 facilities." Sheehan \& Carr, supra note 265 , at 12 . 
state of decreased relevance. In turn, this could be a problem to those emitters who are not required to report to the EPA, such as smaller emitters and non-American sources. Additionally, twenty-six states have developed, or are developing, mandatory GHG reporting rules, many of which go beyond the EPA requirements. ${ }^{277}$ The Registry might have a role to play in supporting reporting under such programs. The EPA also recognizes the importance of voluntary programs, so program co-existence and cooperation might also become a positive result. 278

In addition to the usual benefits of membership, such as technical assistance, networking, and promotional advantages, membership of the Climate Registry enables participants to set a baseline for GHG emissions for use in current and possible future regulatory programs. ${ }^{279}$ This also positions the members to be ready for large-scale emission trading under cap and trade programs, should these become the norm or requirement at a future stage. 280 Further, because the Registry interfaces with several government bodies, it already enjoys quite a bit of legitimacy in the climate regulation context, which is also a solid starting point if emissions trading becomes the order of the day. ${ }^{281}$ Simply put, the Climate Registry is "building the infrastructure for a carbon market," but also for North American registration efforts more broadly. ${ }^{282}$ Finally, the interaction among government-mandated regulatory solutions and purely voluntary, bottom-up solutions is significant in times of still limited government mandates, because it demonstrates how bottom-up solutions have the potential for fossilizing into government mandates at scaled-up levels and, thus, eventually, "hard law." 283 In short, the Climate Registry is an example of how programs that commence as voluntary

277. Id. at 13 .

278. Id. at $13-14$

279. Benefits of Participation, CLIMATE REGISTRY, http://www.climate registry.org/about/benefits-of-participation.html (last visited Feb. 8, 2013).

280. HOFFMAN, supra note 82 , at 89 .

281. Id. at 89-90.

282. Id. at 87 .

283. The North American Energy Reliability Council has demonstrated this potential in the field of energy reliability. See History, N. AM. ENERGY RELIABILITY COUNCIL, http://www.nerc.com/page.php?cid=1|7|11 (last visited Feb. 15, 2013) (discussing the evolution of NERC from a voluntary, informal organization within the energy industry to a central player in the establishment and enforcement of mandatory energy reliability standards). 
programs may, over time and indirectly, obtain mandatory importance.

An analysis of the different roles played by the Climate Registry sheds further light on the broader effects and benefits of this and similar programs. First, the Registry plays an important functional role in standardizing GHG emissions reporting, both for those members that are likely to be regulated by national or regional policies and those that are not. 284 Thus, it serves a "smoothing function" by laying out procedures and protocols for measuring carbon emissions in uniform ways. 285 Through the Registry, climate change leaders can legitimately claim to be so. ${ }^{286}$ In fact, the most important reason for implementing actors to join the Registry is to be recognized for climate leadership. ${ }^{287}$ This stands in contrast to, for example, the Climate Savers program under which some corporations have expressed reservations regarding promoting their environmentally friendly actions externally after recent "greenwashing" debacles. ${ }^{288}$ The Registry is creating a platform for transparency, accountability, and uniformity in a still somewhat controversial branch of science and law.

Additionally, the Registry helps build a significant domestic political carbon registration infrastructure.289 For example, the Climate Registry influenced the EPA as it developed its mandatory GHG reporting rule, issued in 2009.290 Corporations, government entities, and others urged the EPA to adopt Climate Registry procedures, including the third-party verification process, which stands at the core of the Registry's inventory protocols. ${ }^{291}$ The Registry is thus a "powerful platform for subnational governments to engage with the federal governments in the United States and Canada as they (potentially) develop national responses to climate change."292 The Registry is a promising development with the potential for increased future importance should emissions reporting become

284. HOFFMAN, supra note 82 , at 89.

285. Id. at 91 .

286. Id. at 89 .

287. Id.

288. See supra notes $180-81$ and accompanying text.

289. HOFFMAN, supra note 82, at 89-91.

290. Id. at 90 .

291. Id.

292. Id. at 89-90. 
more broadly mandatory. It is an innovative program that is developing at the seams of voluntary and regulated activity and presents a "key example of how experiments work together across governance models ..."293 The program is therefore also an example of vertical cooperation. It also demonstrates the potential for horizontal interfacing with a variety of climate change-related programs at similar levels, whether or not these are, strictly seen, "mandatory," "regulatory," or purely "voluntary."

Further, the program has international potential as its governance and general members include both American and Canadian entities. ${ }^{294}$ The Registry has participated in discussions about globalizing the model and may thereby gain international reach outside the United States and Canada.295 For instance, the Registry is currently working with a Chinese NGO and an environmental department of the government of Israel to help develop registries in those countries.296 The Registry is also participating in discussions about launching similar registries in other areas. ${ }^{297}$ Thus, infrastructure building through the Registry may be going global.298 This is noteworthy because of the potential advantage of having fewer global actors claiming to provide the "best" emissions accounting and reporting oversight (and the "best" programs in general). Homogeneity at a larger, international scale may not only prove more intrinsically sound to the climate change mitigation efforts and programs themselves, but also might establish more external credibility to actors (both corporate and governmental) who have not yet committed to any or much action. These considerations, as well as the potential for governments to interact effectively with non-government units in climate reporting and overall programs, should be taken into account in both the design and implementation of future climate change reduction initiatives.

293. Id. at 91 .

294. Id. at 90 .

295. Id.

296. Id.

297. Id.

298. Id. 


\section{WHAT DOES “SUCCESS” MEAN WITHIN THE CLIMATE CHANGE DISCOURSE?}

Before attempting to evaluate the actual or the potential for success of the above programs, it is necessary to consider which benchmarks to apply in doing so. Substantive carbon reduction improvements are of obvious importance, but other outcome variables are also important to a possible determination of success.

\section{A. BENCHMARKS FOR SUCCESS}

Public participation in the design, implementation, and enforcement of laws and policies is a widely recognized indicator of success not just within climate change, but to law in general.299 However, one school of thought in the climate change context is that "[b]ecause of the underlying uncertainty on [sic] the causation between the best local climate change mitigation policy and the real and concrete impact on a global environmental problem,... efficiency can only be measured procedurally." 300 It "cannot be measured taking into account the quality of the final regulatory result." 301 Whereas there can be no doubt about the many and important benefits of public participation, and it is, to be sure, difficult to trace with exact certainty any possible positive carbon reduction results to just one or a few causes, such difficulty does not warrant the claim that public participation should be the only benchmark for success within climate change or any other area of the law. ${ }^{302}$ Causation uncertainties, as well as other legal and technical difficulties, abound in relation to many other complex areas of the law. ${ }^{303}$ Fortunately, that has not stopped, and should not stop, the discourse about how to measure success more broadly than by merely verifying the degree to which public

299. See generally Karen Syma Czapanskiy \& Rashida Manjoo, The Right of Public Participation in the Law-Making Process and the Role of Legislature in the Promotion of This Right, 19 DUKE J. COMP. \& INT'L L. 1, 4 (2008) ("[L]egislation is better when legislators are required to invite and attend to public input, and... citizenship is better when legislators are required to invite and attend to public input.").

300. Sampaio, supra note 252, at 357 (emphasis added).

301. Id. at 372 (emphasis added).

302. See generally Margaret A. Berger \& Lawrence M. Solan, The Uneasy Relationship Between Science and Law: An Essay and Introduction, 73 BROOK. L. REV. 847 (2008).

303. Id. 
participation is applied in various initiatives. Courses of action, legislative progress, and on-the-ground results can be evaluated retroactively in an attempt to identify general patterns that appear to indicate greater substantive efficiencies than others. Because law and policy are not an exact science, attempting to achieve "exact certainty" in relation to what may work and what may not is too limiting and does not help in moving the agenda forward. This article thus also measures indicia of possible substantive efficacy in addition to public participation.

The best measure of success of environmental initiatives is, in fact, widely considered to be the substantive improvement of environmental conditions, sustainability, and improved energy infrastructures. ${ }^{304}$ As regards to climate change in particular, success measured in terms of actual effects would thus encompass, among other things, reduced carbon emissions, reduced energy consumption in general, and reduced total costs of reducing $\mathrm{CO}_{2}$ levels. ${ }^{305}$ As there is still uncertainty as to how to achieve these goals, flexibility in program designs is also a key benchmark of success within climate change efforts. ${ }^{306}$ As precious time goes by without climate change being addressed sufficiently, it also becomes more and more necessary for effective programs to include adaptation measures in addition to prevention. 307 Adaptation efforts must include components that protect both natural resources and natural services as well as humankind from the coming crises.308 Adaptation and prevention are considered to form part of a "basic litmus test" for regional systems, but of course also apply to national and

304. See, e.g., Laura C. Bickel, Baby Teeth: An Argument in Defense of the Commission for Environmental Cooperation, 37 NEW ENG. L. REV. 815, 849 (2003); Carrie Dolmat-Connell, After Nafta: Can A New International Convention On Toxic Trade Be Far Behind?, 12 B.U. INT'L L.J. 443, 458-59 (1994); J. B. Ruhl, Thinking of Environmental Law as a Complex Adaptive System: How to Clean Up the Environment By Making a Mess of Environmental Law, 34 Hous. L. REV. 933, 988 n. 210 (1997); Andrew Schatz, Discounting the Clean Development Mechanism, 20 GEO. INT'L ENVTL. L. REV. 703, 722 (2008); Susan A. Schneider, Reconsidering the Industrialization of Agriculture, 26 J. ENVTL. L. \& LITIG. 19, 27 (2011).

305. Cf. Kevin Begos, U.S. Carbon Emissions: 2012 Levels at 20 Year Low, HUFFINGTON POST (Aug. 16, 2012, 10:39 PM), http://www.huffingtonpost.com/ 2012/08/16/us-carbon-dioxide-emissions-2012_n_1792167.html.

306. James Olmsted, The Global Warming Crisis: An Analytical Framework to Regional Responses, 23 J. ENVTL. L. \& LITIG. 125, 159 (2008).

307. Id. at $165-67$.

308. Id. 
supranational efforts. ${ }^{309}$

Another layer of analysis can be applied to the above considerations regarding success within climate change efforts, namely what has been termed the "Who, When, and How Test." 310 The "Who" part of the test examines the type of action bodies that are created in connection with new legislation or other relevant action, and who is appointed to such bodies. ${ }^{311}$ Responsible task forces with leaders willing and able to move the agenda forward must be established. ${ }^{312}$ Accordingly, such parties must be willing to fully implement potential new laws to avoid a de facto failure of the "Who" test. 313 They should not, however, have unfettered discretion in how to reach the objectives with which they have been tasked. For example:

[A]n agency often becomes more powerful and has more control over particular outcomes than the legislature, particularly in light of the broad discretion courts usually give agencies. In this case, resources, authority, and discretion can easily become global warming negatives.

Political leaders may come and go, but agency personnel will most often retain their positions through multiple administrations. Once entrenched in their jobs, such agency personnel may develop great power, but then use that power to maintain their own positions rather than bravely striking out to implement the true intent of the law. As can be readily imagined, the Who test may be the most important factor in any analysis of how a bill will work. ${ }^{314}$

The "When" test looks at whether timeframes for action are sufficiently short: "Because time is of the essence in every last effort to mitigate global warming, [a] lack of specificity regarding timing may represent a failure of the When test." 315 The "How" test requires specificity in relation to how to reach the program goals. ${ }^{316}$

Finally, the "success" of any environmental program will have to include a significant mobilization of broad segments of private forces including corporations. Whereas governments and the public-interest sector have important roles to play, solutions that do not seek to involve even broader segments of civil society and the business sector run the risk of becoming

309. Id. at $156-57$.

310. Id. at 157.

311. Id.

312. Id. at $157-58$.

313. Id.

314. Id. at 158 .

315. Id. at $157-58$.

316. Id. at 158 . 
lopsided at best and ineffective at worst. In former UN Secretary-General Kofi Annan's words: “Action starts with Governments.... But Governments cannot do [this] alone. Civil society groups have a critical role, as partners, advocates and watchdogs. So do commercial enterprises. Without the private sector, sustainable development will remain only a distant dream." 317 Christiana Figueres, Executive Secretary of the UNFCCC, agrees, "We need the corporate sector to play a part [in the fight against climate change] and to contribute." 318

\section{B. CAN Local Action Be "Too Successful"?}

Localized climate change action does not only create viable steps towards climate change mitigation and adaptation; there is also a flip side of the coin. The proliferation of local initiatives has demonstrated pitfalls that should be borne in mind and, if possible, avoided in future processes. Some of these negative concerns include the following.

First, "[t]here is a tendency to measure success in the field of environmental law more in terms of legal acts than in terms of actually improving the environment." 319 However, the true measure of success in this field is, of course, whether actual results are achieved. In fact, more and more acts, regulations, and programs may well lead to an inopportune fragmentation of otherwise potentially promising initiatives into disjointed, inhomogeneous action, and thus be counterproductive to the ultimate goal. More concerted action would be better. There is no need to reinvent the wheel again and again, as currently seems to be the direction in which many actors are going. 320 This will not help the agenda out of the stalemate in which it has found itself in recent years. It thus seems that instead of

317. Attila Tanzi, Controversial Developments in the Field of Public Participation in the International Environmental Law Process, in NGOs IN INTERNATIONAL LAW: EFFICIENCY IN FLEXIBILITY? 136 (Pierre-Marie Dupuy \& Luisa Vierucci eds., 2008).

318. Doha Conference Leaders Hail UN Climate Change Agreement, SAUDI GAZETTE (Dec. 11, 2012, 12:34 AM), http://www.saudigazette.com.sa/ index.cfm?method=home.regcon\&contentid=20121211145601.

319. Dolmat-Connell, supra note 304, at 458 (quoting Mostafa Tolba, Report of the Meeting of Senior Government Officials Expert in Environmental law for the Review of Montevideo Programme, Oct. 30-Nov. 2, 1991, U.N. Doc. UNEP/Env.Law/2/3 (Nov. 22, 1991), reprinted in TRANSBOUNDARY MOVEMENTS AND DisPosAL OF HAZARDOUS WASTE IN INTERNATIONAL LAW: BASIC Documents 186 (Barbara Kwiatkowska \& Alfred H.A. Soons eds., 1993)) (internal brackets omitted).

320. See supra notes 85-298 and accompanying text. 
focusing on efficiency and substance, some of these actors are using climate change just as much or more for promotional reasons than for the goal of reaching the actual goals necessary to prevent extreme climate change. ${ }^{321}$ Less fragmentation and more cooperation would be ideal.

Further, when action becomes too widespread, the potential for cost savings due to economies of scale becomes diminished. ${ }^{322}$ From an important technical point of view, some pollutants may also escape limiting action altogether through schemes that are too fragmented: "[B]ecause the sources of GHGs are globally widespread, even ubiquitous, in every country and every sector of the economy, subglobal regulatory coverage fails to control important sources of pollutants." 323

Similarly, an important cross-border "leakage" problem may become the result of action that is "too" localized. 324 "Leakage" denotes situations where subglobal and/or subnational regulations encourage emissions "activities to shift or 'leak' to unregulated areas over time." 325 It can be traced to three causes: "a price effect, a 'slack off' effect, and a capital relocation effect." ${ }^{26}$ The price effect relates to situations in which GHG regulations in one geographical area may affect the prices of and thus demand for certain products in that country with a spill-over effect in another. ${ }^{327}$ Consider, for example, that "restricting forest clearing in Country A would restrict timber supply and raise the world market price for timber, inducing an increase in the quantity of timber harvested in Country B" instead. ${ }^{328}$ Of course, "[t]he magnitude of these effects depends on ... how much the activity levels change in response to price changes ... and on the degree of integration

321. Olmsted, supra note 306, at 158.

322. See Cinnamon Carlarne, Notes from a Climate Change PressureCooker: Sub-Federal Attempts at Transformation Meet National Resistance in the USA, 40 CONN. L. REV. 1351, 1355, 1371 (2008) (discussing uniformity and economies of scale as traditional justifications for environmental regulation at the federal level, and applying these principals to regional approaches to climate change).

323. Jonathan B. Wiener, Think Globally, Act Globally: The Limits of Local Climate Policies, 155 U. PA. L. REV. 1961, 1967 (2007).

324. Id.

325. $I d$.

326. Id. at 1967-68.

327. Id.

328. Id. at 1968. 
of world markets for the relevant goods and services."329 Second, "restrictions on emissions in Country A could induce emissions-intensive industries to uproot and relocate facilities to unregulated Country B" for cost-savings reasons. 330 Third,

[t]he "slack off" effect is a response to changing national net benefits. In the absence of a treaty, Country A might undertake some abatement, just to the point where its (small) domestic share of the global marginal benefits equals its domestic marginal costs of abatement. Country B would do likewise. But if Country A begins to abate its own emissions more aggressively, some additional global protection would be obtained, and the marginal benefit to Country B of its own abatement efforts would be diminished slightly (on the standard assumption of diminishing marginal benefits of protection), so that the domestically rational degree of abatement in Country B would fall. Hence, as some states emit less, other states rationally emit more. ${ }^{331}$

The leakage considerations apply to both the global regime and to the United States system if regulations are taken at the subnational level without coherence provided by federal umbrella provisions. ${ }^{332}$ Whereas these considerations are important and must be addressed in the development of future localized climate solutions, they should not be allowed stop or slow down the currently necessary development of the area.

\section{THE STATUS: IS IT WORTH PURSUING CLIMATE CHANGE ACTION AT THE LOCALIZED LEVEL?}

This section will apply the above factors for determining the possible success of climate change programs to the described initiatives in order to analyze whether action at the subnational level already is or is likely to become successful as seen from both the procedural and the substantive points of view. For the sake of brevity, and to follow the scholastic benchmarks for success set forth above, the factors are grouped into the "actor" and "substance" categories. The "actor" analysis will ascertain whether there is a risk that program leaders have too much discretion, whether public participation is required, whether corporations are involved, and whether polycentric action, in general, forms a part of the programs. The "substance" analysis will establish whether any promising on-the-ground indicators or results can currently be identified,

329. Id.

330. Id.

331. Id.

332. Id. at $1968-69$. 
whether program goals operate within a sufficiently narrow timeframe, and how the initiatives plan to meet their goals.

\section{A. Action at the Private, Voluntary LeVel: CRAGs AND the NUDGE THEORY}

This article has examined CRAGs as an example of a bottom-up solution initiated without any government mandates or interaction, but with self-imposed compliance enforcement. ${ }^{333}$ Such voluntary NGO action has, at least until recently, been widely touted as a promising possibility for success, especially since government units remain as reluctant to act as they do. ${ }^{334}$ However, the answer to whether such action will suffice in relation to climate-change action, must, on balance, be "no."

First, CRAG actors are not powerful enough. ${ }^{335}$ While the "Who" test referenced above mentions concern over authoritative program leaders with unfettered discretion over action, ${ }^{336}$ experience shows the opposite: the CRAG programs tend to be led by peers who must agree upon what action to take and how to reach the goals. ${ }^{337}$ Where such unity is laudable in theory, clearer top-down leadership must also be a part of successful programs. 338 Within the CRAG scheme, however, this vital component appears to be lacking. ${ }^{339}$ Additionally, participation by distinct groups of actors is

333. See supra Part III.A.2.

334. See Boyd Cohen, U.S. NGOs that are Moving the Needle on Climate Change, TRIPLEPUNDIT.COM (Mar. 31, 2011), http://www.triplepundit.com/ 2011/03/ngos-moving-needle-climate-change/ ("[T]here are so many NGOs doing powerful work to make the low-carbon shift at local, regional, national and international levels ....").

335. HOWELL, supra note 30, at 4, 11-12, 14-15 (discussing CRAG problems such as inactivity of members, manipulating carbon quotas by giving children their full quota while they really need less, and ability or willingness of members to pay carbon quota fines voluntarily).

336. Olmsted, supra note 306 , at 258.

337. See HowELL, supra note 30, at 3-4 (discussing that CRAGs are really "groups formed to encourage members to reduce their carbon footprints" by holding themselves accountable).

338. Cf. Richard W. Scholl, Leader Behavior and Motivation, U.R.I., http://www.uri.edu/research/lrc/scholl/webnotes/Leadership_Behavior.htm (last visited Feb. 7, 2013) ("Effective leadership is viewed by most people as fundamental to the success of any organization.").

339. HOWELL, supra note 30, at 23-27. 
limited. ${ }^{340}$ CRAGs serve only private interest groups whereas polycentric action typically includes interaction among government units, corporations, in addition to private interest groups. ${ }^{341}$

Second, the most important problem in connection with the substance of the CRAG initiative is the apparent lack of continued or renewed activity among participants. ${ }^{342}$ This is unfortunate given that some CRAGers have reduced their carbon footprint by up to $27 \%$ in the first year of operations. ${ }^{343}$ With continued participation, these groups could attain substantively far-reaching goals of up to $10 \%$ GHG reductions per annum. ${ }^{344}$

On the other hand, while continued participation may be lacking, ${ }^{345}$ there are promising aspects of CRAGs. For one, at least some people accept fines in binding GHG-reduction schemes. ${ }^{346}$ Where some governments have not yet adopted such penalties, acquiescence to self-imposed fines among CRAG members could be comparatively noteworthy for lawmakers. ${ }^{347}$ However, how broadly such an enforcement scheme would be accepted by civil society not only in the United Kingdom, but especially in the more heavily emitting nations such as the United States, is beyond the scope of this article. Suffice it to say, fines imposed upon private individuals for exceeding carbon rations would undoubtedly meet with resistance in many places. ${ }^{348}$ The CRAG scheme also illustrates how laws

340. Cf. Elinor Ostrom, A Polycentric Approach for Coping with Climate Change 35 (World Bank, Working Paper No. 5095, 2009) ("[M]ultiple benefits are created by diverse actions at multiple scales.").

341. See id. at 4 ("To solve climate change in the long run, the day-to-day activities of individuals, families, firms, communities, and governments at multiple levels-particularly those in the more developed world-will need to change substantially.").

342. HOWELL, supra note 30, at 23-28.

343. Id. at $18-19$.

344. Id. at 11 .

345. Id. at $23-28$.

346. Id. at 13 ("Of the 24 'active' CRAGs listed on the website, 14 definitely have a financial penalty for exceeding the carbon target, ranging from $2 p$ to 10 p per kilogram ...").

347. But see Australian Gov't, DEP'T of SustainabiLity, EnV'T, WATER, POPULATION \& COMMUNITIES, COMPLIANCE AND ENFORCEMENT ARRANGEMENTS FOR SYNTHETIC GREENHOUSE GASES 3 (2012), available at http://www.environment.gov.au/atmosphere/ozone/sgg/equivalentcarbonprice/p ublications/pubs/fs8-ecp-compliance.pdf.

348. HowELL, supra note 30, at 13 ("The idea of a fine for going above a certain amount was thought that it would put potential members off."). 
that are seen as sound from a personal and social perspective will meet with greater acceptance than those that are not. ${ }^{349}$ It is thus important to continue to bring attention to the potential threats associated with climate change to garner broad support for legislation. ${ }^{350}$ Focus on the threat of climate change, however, has regrettably been decreasing in recent years. ${ }^{351}$

Outside of CRAGs and climate change, private action without government mandate has, by way of comparison, been promoted under such names as the "nudge theory." 352 Described by the authors as "libertarian paternalism," 353 the nudge theory was popularized by law professor Cass Sunstein and economist Richard Thaler in their recent book on how to influence private behavior without offering financial incentives or imposing government sanctions. ${ }^{354}$ Similarly, Christiana Figueres has also recently called for private citizens to "assume responsibility" for climate change, although she did not specifically label her call a "nudge." 355 For a policy to be a nudge, it has to involve changing our physical or social environment in a way that does not restrict our choices or change financial incentives. ${ }^{356}$ For example, successes in behavioral change through nudges may include attitudes

349. See id. at 23 ("[I]nterviewees from WSP mentioned increased awareness and understanding of their emissions as benefits of being involved in the scheme ...”). WSP is a geographically dispersed CRAG. See id.

350. Cf. Tomiko Brown-Nagin, Elite, Social Movements, and the Law: The Case of Affirmative Action, 105 COLUM. L. REV. 1436, 1447 (2005) (discussing how public awareness and media were used to effectively lobby affirmativeaction legislation).

351. Rob Jordan, Support for Climate Change Action Drops, Stanford Poll Finds, STAN. NEWS (May 8, 2012), http://news.stanford.edu/news/2012/ may/climate-change-survey-050812.html.

352. See generally RichaRd H. THALER \& CAss R. Sunstein, NudGe: Improving DeCisions About HeAlth, WeAlth AND HapPiness (Yale Univ. Press 2008) (describing the nudge theory).

353. Id. at 5 (defining libertarianism as "liberty-preserving" with the aim of not burdening those who want to exercise their freedom and "paternalism" as trying to influence people's behavior and choices in directions that will make choosers better off, as judged by themselves).

354. See generally id.

355. Karl Ritter, Christiana Figueres, UN Climate Chief, Says Individuals Need to 'Assume Responsibility' to Address Problem, HufFInGTON Post (Nov. 30, 2012, 7:38 AM), http://www.huffingtonpost.com/2012/11/30/christianafigueres-un_n_2217056.html.

356. Baroness Julia Neuberger, Why a Nudge is Not Enough to Change Behaviour, BBC NEws (July 18, 2011, 8:54 PM), http://www.bbc.co.uk/ news/health-14186806. 
towards smoking reduction, 357 taking shorter showers, 358 turning off lights when leaving a room, 359 attitudes towards eating healthily, 360 and discouraging intoxicated driving. 361 Examples of nudges within the environmental field include the use of thermostats that state the cost per hour of increasing or decreasing room temperatures. ${ }^{362}$ A company has already designed a relatively inexpensive unit that wirelessly connects to a home's energy meter and displays electricity usage in watts or money. ${ }^{363}$ A blue glow indicates that less electricity than usual is being used; a red glow means the opposite. 364 This is considered more helpful in effectuating actual change among consumers than are more lofty informational campaigns. 365 Other countries, such as Japan, Great Britain, and France, also seem to be endorsing the "nudge" approach. 366 These countries display, or are planning to display, a product's carbon footprint on product labeling in order to raise public awareness about global warming. ${ }^{367}$ Perhaps most indicatively,

357. Jonathan Ball, Nudge Tactics No "Magic Bullet," BBC NEws (Sept. 6, 2012, 11:40 AM), http://www.bbc.co.uk/news/science-environment-19506608.

358. See, e.g., Take Shorter Showers, Bos. U. SUSTAINABILITY, http://www.bu.edu/sustainability/what-you-can-do/ten-sustainableactions/take-shorter-showers/ (last visited Feb. 7, 2013).

359. See, e.g., When to Turn Off Your Lights, ENERGY.GOV (Aug. 30, 2012, 7:53 PM), http://energy.gov/energysaver/articles/when-turn-your-lights.

360. See, e.g., Eat Healthy, LETSMOVE.GOV, http://www.letsmove.gov/eathealthy (last visited Feb. 7, 2013).

361. See, e.g., Five Minutes or Less for Health Weekly Tip: Don't Drink and Drive, CDC, http://www.cdc.gov/family/minutes/tips/dontdrinkanddrive/ index.htm (last visited Feb. 7, 2013).

362. See generally Smarthours Questions and Answers, OGE.COM, http://www.oge.com/residential-customers/products-and-services/Pages/

SmartHours.aspx (last visited Mar. 25, 2013) (detailing a thermostat program that shows energy cost savings).

363. Id.; Ambient: Information at a Glance, AMBIENT DEVICES, http://www.ambientdevices.com/ (last visited Mar. 26, 2013).

364. THALER \& SUNSTEIN, supra note 352, at 194.

365. See generally VincENT P. GAMBAL, PUBliC Information CAMPAigns: AN APPLICATION OF THE THEORY OF REASONED ACTION (1990), available at http://www.udel.edu/communication/web/thesisfiles/gambalthesis.pdf

(discussing the range of effectiveness on informational campaigns as relatively effective to completely ineffective).

366. See Britain Shapes Good Citizens with a Gentle 'Nudge,' JAPAN TIMES (Feb. 4, 2013), http://www.japantimes.co.jp/news/2013/02/04/world/britainshapes-good-citizens-with-a-gentle-nudge/\#.URQsLmdhW8A; Carbon Footprint Labels are Spreading, NUDGE BLOG (Aug. 21, 2008), http://nudges.org/2008/08/21/carbon-footprint-labels-are-spreading/

[hereinafter Carbon Footprint Labels].

367. See Carbon Footprint Labels, supra note 366. 
the Sacramento Municipal Water District uses a simple, reader-friendly Home Electricity Report that specifies how the users' energy use compares with that of both their "efficient neighbors" ("those that fall under a specified standard") and "all neighbors." 368 This report ranks people's energy use "as great, good, or below average (with one smiley face for good, and two for great)." 369 Furthermore, these users are "shown how their own [energy] use compares with that of their efficient neighbors [by] percentages and bar charts. ('Last month, you used 40 percent more electricity than your efficient neighbors.)"370 Finally, customers are shown in big letters how much money they are paying per year as a result of their possible inefficiency ("At today's rates this COSTS YOU ABOUT \$358 PER YEAR"). ${ }^{371}$ Additionally, and importantly, "consumers are also given 'personalized [energy-saving] tips' that are specifically 'based on [their] energy use and housing profile" (such as unplugging appliances, smart purchases, and investments in maintenance of heating/cooling systems). ${ }^{372}$ In this manner, specific and realistic energy-saving options may aid climate change goals more than common factual messages such as "stop flying" or "help save the environment," as is often displayed on hotel room signs asking patrons to consider reusing towels instead of having them washed, which are considered less effective. ${ }^{373}$

Although nudge theory is an appealing and promising idea, it may be necessary to simply "force," not just nudge, action against climate change whether through legal and/or financial methods such as carbon taxes or tax credits. Indeed, the authors of Nudge recognize the "status quo bias," where, in general, people "have a more general tendency to stick with their current situation." 374 This may explain the inability to instigate present-day action within climate change, which is still largely seen as a "future" problem. In contrast, the ozone

\footnotetext{
368. Richard H. ThaleR \& CASS R. Sunstein, NudGE: IMPROVING DeCisions About Health, Wealth AND HapPiness 259 (Penguin Books 2009).

369. Id.

370. Id.

371. Id.

372. Id.

373. E.g., Andrews, supra note 103, at 43 (discussing CRAGs as a "practical implementation of a well-researched policy").

374. THALER \& SUnsteIn, supra note 352, at 34-35.
} 
depletion problem, arguably initiated a greater willingness to act due to the problem's here-and-now effect (fears at the time were of losing one's eyesight due to the lack of a protective ozone layer). 375

The UK is one of the nations that, so far, has favored the "nudge," approach to various problems, but a recent report by the British Government Committee concludes that nudges alone won't work. ${ }^{376}$ It may be necessary to use a range of different policies, including government regulation. ${ }^{377} \mathrm{~A}$ recent poll, for example, found that "while recycling is widespread in America and $73 \%$ of those polled are paying bills online in order to save paper,' only four percent had reduced their utility use and only three percent had purchased hybrid cars." 378 Although this a step in the right direction, it is not enough: "Given a hundred years, you could conceivably change lifestyles enough to matter-but time is precisely what we lack." ${ }^{379}$ Professor Lord John Krebs concurs in findings presented at a recent British Science Festival: nudges are successful in some areas, but not always. ${ }^{380}$ They should not be regarded as a "get out of jail free" card by governments wishing to avoid tougher approaches like regulation or taxation. ${ }^{381}$ Instead, a combination of approaches-social nudging, regulation, taxation, and investment-may be most effective in relation to time sensitive problems such as climate change. ${ }^{382}$

In short, action at the purely private level will not suffice to solve the climate change problem. If privately initiated programs were interfaced with programs with more binding authority and resources, their success rate would have potential to increase.

375. See Ozone Depletion-Why It's a Problem, ECOEvaluator.Com, http://www.ecoevaluator.com/environment/air-quality/ozone-depletion.html (last visited Feb. 7, 2013).

376. Neuberger, supra note 356 ("[F] us at the moment, the science says that 'nudging' won't be enough.").

377. Id.

378. McKibben, supra note 13 , at 56 .

379. Id.

380. See Amy Richards, The Nudge Debate-A Strategic Approach Gets Results, DIVACREATIVE.COM (Sept. 2012), http://www.divacreative.com/blog/ the-nudge-debate-a-strategic-approach-gets-results/.

381. Ball, supra note 357.

382. Id. 


\section{B. ACTION AT THE City LEVEL: EU COVEnANT OF MAYORS AND GREENCLIMATECITIES ${ }^{383}$}

Action at the city level appears to be the most promising of the initiatives analyzed here. From a positive angle, because the programs constitute cooperation among cities equally situated within the programs, the risk of actors that are "too" powerful from an organizational point of view does not appear to be a problem. ${ }^{384}$ Nonetheless, one may fear that some cities may, over time, capture the de facto leadership of these programs-whether for altruistic or more self-focused reasons-and thus obtain inexpediently strong leadership roles vis-à-vis other cities. This concern should, however, be addressed internally through proper procedural preventative measures. The following comparison between the EU Covenant of Mayors and GreenClimateCities explains why.

The EU Covenant of Mayors attempts to motivate civil society to cooperate with the member cities in developing action plans. ${ }^{385}$ This seems to be a procedurally sound practice. In contrast, GreenClimateCities does not seem to emphasize public participation in its documentation. ${ }^{386}$ The program is still new, so, giving it the benefit of the doubt, the correction of these issues may well be in the pipeline, which would be desirable for the reasons established above. The EU Covenant of Mayors attempts to share information with other territorial units, and thus to undertake at least some, albeit not much, polycentric action. ${ }^{387}$ The focus on territories, however, seems to indicate that the Covenant does not plan to involve Public-Interest NGOs (PINGOs) or Business-Interest NGOs (BINGOs) to a significant extent in its work. When the research for this article

383. The MCPA has purposefully been omitted from this section due to the organization's lack in updating commitments at the end of 2012 when this article was written.

384. This of course remains a concern at the individual city level, where mayors may have relatively large amounts of power depending on the democratic design in question. Dellinger, supra note 1 (manuscript at 31) (discussing how public participation helps to avoid "ivory tower decisions"). In the climate context, however, "strong" mayors have helped the agenda forward, such as in the cases of New York and Seattle. See id. (manuscript at 56-58, 67-76); U.S. Conference of Mayors Climate Protection Agreement, supra note 202 .

385. See TOWARDS A LOW CARBON FUTURE, supra note 89.

386. See generally GREENCLIMATECITIES, supra note 222.

387. TOWARDS A LOW CARBON FUTURE, supra note 89, at 4. 
was concluded, GreenClimateCities did not mention any type of polycentric cooperation in its materials beyond the obvious cooperation among the governance members themselves. ${ }^{388}$ Cities or other governmentally established geographical units will thus be the only responsible parties under both the EU Covenant and the GreenClimateCities programs. But polycentric action is a recognized benchmark of success, especially if both business- and public-interest NGOs are involved in the same programs. ${ }^{389}$ This consideration could also be applied to the city level and should thus be taken into account for greater possibilities of effectiveness and inclusiveness in city coalition programs.

Substantively, the EU Covenant of Mayors program appears to be promising. The $20 \%$ reductions goal by 2020 is positive. ${ }^{390}$ However, it is important to remember that, by definition, this goal only accounts for one-fifth of the total effort required by the EU, thus still leaving no less than four-fifths of the goal to be accomplished by non-members, including many rural areas. Although some less urbanized areas such as counties and metropolitan districts have joined the initiative, members are typically towns, cities, and other relatively urbanized areas. ${ }^{391}$ Given the fact that most sources of $\mathrm{CO}_{2}$ (i.e., power plants, companies, and urban residents) are found in urban areas, one would have hoped that by now, the umbrella goals of such urban areas would have reached farther than the arguably still meager $20 \%$. At the same time, it should be remembered that other official and unofficial programs also overlap with or compare to the Covenant. 392 This patchwork situation is not ideal as it is not only difficult to overview, but also creates risks that gaps exist and remain unnoticed in what should ideally be an all-encompassing blanket. ${ }^{393}$ Nonetheless, it is promising that clear reductions goals have been announced under the EU Covenant, that these goals will not be met solely or mainly by cap-and-trade programs but by actual emissions reductions, that there is a specific year for goal fulfillment that is not too distant, and that the program is spreading to other

388. See generally GREENCLIMATECITIES, supra note 222.

389. See generally Ostrom, supra note 340.

390. See TOWARDS A LOWER CARBON FUTURE, supra note 90, at 3.

391. COVENANT OF MAYORS, 4286 SigNATORIES (2013), available at http://www.eumayors.eu/covenant_signatories.pdf.

392. See TOWARDS A LOWER CARBON FUTURE, supra note 90, at 6 .

393. Sheenan \& Carr, supra note 265, at 12. 
parts of the world than just the EU. It is also noteworthy that some EU actors are willing to exceed the established targets. ${ }^{394}$ This compares favorably to the ClimateSavers program under which some corporations employ similar "stretch targets" that ask them to go further than what they originally thought they could and bodes well for quasi-voluntary action. ${ }^{395}$ In contrast, the goals and enforcement methods of the GreenClimateCities are somewhat unclear at this point in time. ${ }^{396}$

In short, action against climate change at the city level is promising. Most importantly though, climate change programs should be considered against the risk of overcrowding by a proliferation of too many patchwork programs and actors, most of whom invariably claim to have the best solution(s) to the problem and be the next leaders of action at the sub-national, sub-state level. It would instead be preferable if larger government units and supranational organizations would (re-)enter the scene to cooperate and otherwise interface legislatively, practically, and politically with the city actors. This is so because there are, as amply demonstrated elsewhere, many roles that only such larger units can undertake or that they are best positioned to undertake. ${ }^{397}$ Importantly here, larger governance units can create and enforce umbrella action goals, which could help alleviate the above-mentioned problem of overcrowding. ${ }^{398}$ Further, deeper and broader involvement by state, national, and supranational actors would not only lend more force to the regime in general, but also more credibility to

394. Covenant of Mayors News, COVEnANT of MAYORS, http://www. covenantofmayors.eu/index_en.html (last visited Feb. 7, 2013) ("By their commitment, Covenant signatories aim to meet and exceed the European Union 20\% CO2 reduction objective by 2020.").

395. World Wide Fund For NATURe, The Climate SAVERs Programme: How Corporations CAN SAVE the Climate 19 (2007) [hereinafter The Climate SAVERS PROGRAMME], available at http://awsassets.panda.org/ downloads/cs_web_version_may2008_1.pdf ("The reductions-described within the company as 'stretch targets' will be achieved through a mix of energy efficiency and renewable energy projects carried out at Novo Nordisk operations globally.").

396. See generally GREENCLIMATECITIES, supra note 222.

397. Dellinger, supra note 1 (manuscript at 18-19).

398. See generally NATIONAL ACTION PLAN: COMMUNICATIONS UMBRELLA (2011), available at http://www.demandresponsesmartgrid.org/Resources/ Documents/NAP\%20Docs/NAPC\%20Action\%20Guide\%20Part\%201\%2011.07.0 7.pdf. 
action taken in cooperation with actors at lower levels. 399

Cities have demonstrated the potential for innovative and effective action within areas other than climate change. For example, the San Francisco ban on free plastic grocery bags has spread to such cities as Los Angeles, California;400 Toronto, Canada; 401 and Delhi, India. ${ }^{402}$ Other cities, such as Santa Fe, New Mexico, are considering the ban as well. ${ }^{403}$ Many jurisdictions-seventy in California alone-have approved bans on polystyrene cups and food containers. ${ }^{404}$

New York City adopted a more controversial ban on the sale of large-sized sodas for health reasons. ${ }^{405}$ The long-term viability and success of New York City's ban remains to be seen as it was recently declared invalid and an appeal is pending. ${ }^{406}$ However, it still bodes well for climate change governance that effective legislative and other action does spring up at the city level, even when not required by state or national bodies.

399. See Tiffany Stecker, Adaptation: Companies Tackle 'Weird Water' Risks Head-On, EENEWS.NET (Sept. 4, 2012), http://www.eenews.net/ public/climatewire/2012/09/04/2 (discussing how the SEC findings were able to "lend credibility" to climate risk companies).

400. Plastic Bag Ban, supra note 3.

401. Michael Lauzon, Plastic Bag Manufacturers Take Legal Action Against Toronto Bag Ban, PLASTICSNEWs.COM (Nov. 20, 2012, 12:25 PM), http://www.plasticsnews.com/headlines2.html?id=27079\&channel=450.

402. Tyler Falk, Delhi Imposes Complete Ban of Plastic Bags, SMART PlANET (Sept. 12, 2012, 10:20 AM), http://www.smartplanet.com/blog/cities/ delhi-imposes-complete-ban-of-plastic-bags/5192.

403. Telephone Interview with Katherine Mortimer, Programs Manager, Sustainable Santa Fe with Myanna Dellinger, Assistant Professor of Law, W. State Coll. of Law (Aug. 16, 2012); see also Solid Waste Reduction, Sustainable Santa Fe, SANTA FE 400, http://www.santafenm.gov/index.aspx?NID=1367 (last visited Feb. 7, 2013) ("Seek funding to develop a reusable bag, with the option of stores adding their logo, along with a 'Sustainable Santa Fe' logo, to encourage bag reuse. This can be combined with an ordinance restricting free bag distribution from stores.").

404. See Wendy Koch, Cities Have 'Tidal Wave' of Bans on Foam Containers, USA TODAY, Dec. 13, 2012, at A3.

405. Daniel Engber, Fuzzy and Fizzy: The Contested Science Behind Bloomberg's Ban on Large-Sized Sodas, SLATE.COM (Sept. 13, 2012, 1:15PM), http://www.slate.com/articles/health_and_science/science/2012/06/bloomberg_b ans_large_sized_soda_the_science_behind_the_decision_html. However, this ban is controversial and may not go into effect. See NYC Soda Ban Rejected: Judge Strikes Down Limit on Large Sugary Drinks as 'Arbitrary, Capricious,' HUFFINGTON POST (Mar. 11, 2013, 11:46 AM), http://www.huffingtonpost .com/2013/03/11/nyc-soda-ban-dismissed-judge-large-sugary-

drinks_n_2854563.html.

406. Michael Howard Saul, Judge Cans Soda Ban, WALL ST. J., Mar. 12, 2013, at A19. 


\section{Action at the Established NGO-Level: Climate SAVers}

Environmental discourse often laments the lack of corporate involvement in non-governmentally mandated climate change solutions. ${ }^{407}$ The Climate Savers program is an example of how corporations $d o$, in some instances, voluntarily involve themselves in climate work. ${ }^{408}$ The program is also an example, at least in this instance, of how corporations take this a step further and cooperate successfully with a PINGO, namely the WWF, which oversees Climate Savers. ${ }^{409}$ The BINGO-PINGO cooperation itself demonstrates a procedurally successful aspect of the program. This type of cross-sectoral NGO cooperation is very promising.

Public participation-generally a hallmark of procedural success 410 -is not directly relevant to Climate Savers, at least not to the same extent as with government programs. This is because the Climate Savers program is by definition an initiative by and for the public, in this instance companies, ${ }^{411}$ whereas the public participation concern centers more on traditional governance units. ${ }^{412}$ Of course, expanded cooperation with government entities at any level and with other PINGOs or BINGOs would be desirable.

On the other hand, a concern when measuring the success of environmental programs is, as always, whether implementing or other leading actors may become too powerful in relation to other internal and external actors. 413 The Climate Savers program brings forward this concern. The program membership includes corporate giants with the potential for paving the way in positive, but arguably also in negative, ways. ${ }^{414}$ Most environmentally interested stakeholders appear to share the concern that with the large amount of corporate resources, and thus potential for leverage possessed by the type of companies involved in programs such as Climate Savers, comes the risk of excessive influence both within the program and externally. In the United States, corporations are widely

407. See supra note 301 and accompanying text.

408. See supra Part III.B.

409. Id.

410. See supra Part IV.A.

411. See supra note 165 and accompanying text.

412. See Dellinger, supra note 1 (manuscript at 29-30).

413. See supra note 304 and accompanying text.

414. See supra text accompanying note 167 . 
considered to have already "captured" many government units. ${ }^{415}$ This concern also applies to the private organizational level where leadership could similarly be captured by the strongest actors. After the United States Supreme Court's decision in Citizens United v. Federal Election Commission, 416 fears that corporations can and do yield excessive powers-not only within certain circles such as the groups of which they are members, but also in society at large-are certainly not shrinking. ${ }^{417}$ After environmental scandals such as the BP disaster, the fear of corporations proclaiming to be environmentally "friendly," only to actually remain on a traditional profits-above-everything-else course, remains very real. 418

The risk, as demonstrated in Part IV.A, is one of unfettered discretion. In the Climate Savers network, it does not appear that any given corporation enjoys disproportionately broad powers in relation to other members or to the program leadership. However, civil society's general concern that with "leadership" and prominence comes the risk of negative dominance is understandable. It is a concern that Climate Savers should address with external stakeholders for a greater level of approval among, in particular, non-corporate stakeholders in the climate process at large. On balance, however, it is fair to consider Climate Savers a procedural success because of, in particular, its PINGO/BINGO interface, the reliable nature of the oversight and well-established NGO, and the clear processes for goal-fulfillment. ${ }^{419}$

Climate Savers also appears substantively promising. In particular, the program's use of stretch targets indicates a corporate awareness that more action-and not the resistance for which many corporations are notorious in the climate context-is needed to achieve substantively successful climate

415. See, e.g., Robert A.G. Monks, The Corporate Capture of the United States, HaRV. L. SCH. F. ON CORP. GOVERnANCE \& Fin. REG. (Jan. 5, 2012, 10:21 AM), https://blogs.law.harvard.edu/corpgov/2012/01/05/the-corporatecapture-of-the-united-states/ ("The financial power of American corporations now controls every stage of politics-legislative, executive, and ultimately judicial.”).

416. Citizens United v. Fed. Election Comm'n, 558 U.S. 310 (2010).

417. See Jill Greenfield, Experts Assess Impact of Citizens United, HARV. GAZETTE (Feb. 3, 2012), http://news.harvard.edu/gazette/story/2012/02/ experts-assess-impact-of-citizens-united/.

418. See supra notes 55-58, 197 and accompanying text.

419. See supra Part III.B. 
goals. ${ }^{420}$ Further, companies have already achieved two-digit reduction percentages while the Kyoto Protocol was operating with single-digit reduction percentage figures, at least until very recently. ${ }^{421}$ It is also noteworthy that these companies have achieved their reductions while increasing corporate sales growth, even in today's financially very difficult circumstances. ${ }^{422}$ The fact that not insignificant emissions reductions are well underway at the voluntary, corporate level is a substantive success, as is the program's focus on thirdparty compliance review. 423

In short, it is worth pursuing voluntary action at the BINGO level, although some risk factors exist. Cynics will point out that companies may simply participate in programs such as Climate Savers because of public relations advantages, the potential for corporate savings, the risk of shareholder hostility and potential lawsuits if not taking action, or because companies realize that regulations appear inevitable in the long run. ${ }^{424}$ At any rate, it cannot reasonably be disputed that, regardless of motivation, it is positive that some action is taken by the corporate world. Broader, more far-reaching corporate action would be even better. However, the fact that many large and well-known companies cooperate with Climate Savers has the potential to create a trend that other perhaps more resistant companies will not be able to avoid in the long run for a variety of reasons. In combination with the pressure exerted by city, and hopefully soon national and international governance units, there may be grounds for hope that companies will soon form a larger active part of possible solution to the climate change challenge.

\section{Multi-Sector Action: The Climate Registry}

Reliable, accurate, and transparent carbon accounting and registration are necessary for progress against climate change at any front. Third-party oversight lends necessary credibility

420. The Climate SAVERS Programme, supra note 395, at 19; supra notes 172-73 and accompanying text.

421. See supra notes 60, 189 and accompanying text.

422. For example, Johnson \& Johnson simultaneously surpassed a reduction target while increasing sales growth in 2010. Supra notes 188-90 and accompanying text.

423. See supra notes $174-75$ and accompanying text.

424. See supra notes $180-86$ and accompanying text. 
to carbon reduction programs and allows for future enforcement based on data that is accessible and verifiable by the overseeing bodies. Because of the highly technical and global nature of the underlying problem, uniform or at least comparable standards are necessary. The Climate Registry is one example of a platform for addressing these concerns. It demonstrates the possibilities for successful interaction among city, state, federal, and tribal government entities as well as across to civil society represented via BINGOs and/or PINGOs.

The program also is an example of how programs may expand from purely voluntary, bottom-up action to having regulatory implications if or when governments start requiring the type of service that programs such as the Climate Registry provide.425 Vertical and horizontal cooperation among government and civil society actors is key in the environmental arena as well as more broadly. The Climate Registry exemplifies the possibilities of such cooperation. Where this can be expanded to the international level, such as is likely in the case of the Climate Registry, the potential for success also expands. But the risk of overcrowding also exists when it comes to carbon registration. In the United States, both the Climate Registry and the EPA provide registration options. ${ }^{426}$ The carbonn Cities Climate Registry offers registration options internationally. ${ }^{427}$

Ironically, polycentric, bottom-up action is necessary to truly move the climate change agenda forward, while at the same time too much bottom-up action poses separate risks. Nonetheless, this is the reality- "too much" of something is not good, but neither is "too little." A reliable, workable, and trustworthy medium needs to be developed. This medium must allow for a healthy amount of competition among program solutions, perhaps even when it comes to registries. Time, government action or inaction, public opinion, and the marketplace will contribute to finding workable solutions. In the meantime, actors with power to move the development in the qualitative right direction should be aware of pitfalls posed by focusing too narrowly on success for their own programs only. These actors should also-as arguably is the case already - consider the benefits of synergism between programs on at least the international level where registries can co-exist,

425. See supra Part III.D.

426. See supra notes 268, 73 and accompanying text.

427. See supra notes 224-27 and accompanying text. 
even if this may not be the case at the national levels for reasons of competition.

\section{CONCLUSION}

Climate change requires imminent action from as many angles as possible. No one single solution is sufficiently promising at this very late point in time. However, this much is clear: waiting for national-level and supranational-level actors to take substantively effective action in broad agreement with a majority of other similarly situated actors is like waiting for Godot-unlikely to happen, at least at an early enough point in time. This article posits that local initiatives currently present the most promising course of action for effective climate change solutions. The article analyzes subnational, substate programs with either no enforcement methods, limited methods, or traditional methods. Of such local initiatives, the most promising sources of procedural and substantive success are those that are not scaled down to the purely private level, but rather include involvement and oversight by somewhat larger and more well-established bodies such as city coalitions or recognized NGOs. Traditional law enforcement is not an indispensable component of effective local climate change initiatives; other modernly recognized methods of alternative compliance securement can, if used correctly, be just as or even more viable.

Opponents of local action may argue that there is no time for local action within climate change. The response to this is that there is only time for this. Although action by and an interface to larger-scale governance units is still desirable if it could be obtained, experience shows that we must look to nontraditional actors to continue to step up climate-change action to meet the climate challenge in the timeframe called for by scientists. This is even more evident after the parties to the climate change treaty negotiations under the UNFCCC regime failed to agree on a broadly accepted renewal of the expired Kyoto Protocol to take immediate effect, but instead only reached an agreement that a second legally binding agreement should be developed, adopted, and take effect by 2020.428 One can hope that such an agreement will be drafted, but with the uncertainties that abound in relation to what, after all,

428. Arup, supra note 64 . 
amounts to mere hopes for a future that nobody can predict, this is far from certain to be the case. ${ }^{429}$ In fact, the discussions only weakened the second commitment period of the already too modest Kyoto Protocol since the few parties who adopted secondary binding emissions cuts by 2020 only account for approximately $15 \%$ of global emissions. ${ }^{430}$ It seems impossible to reach a broad and sufficiently deep solution by all parties to the UNFCCC. On that scale, only narrower solutions such as "clubs" of countries with a much more limited membership and shared interests seems to be the best hope.

Climatologists continue to warn of a tipping point after which the world is unlikely to be able to reverse unforeseeable, but in all likelihood extreme and dangerous effects of climate change. ${ }^{431}$ However, we may also reach a much more positive tipping point-one at which action by a yet relatively small amount of participants reaches such a critical mass that effective climate change reduction becomes the order of the day and not mere rhetoric about what could be. At that point in time, the law of the few will be the law of the many. ${ }^{432}$

429. Ad Hoc Working Group on Further Commitments, supra note 62.

430. See Ritter \& Casey, supra note 63.

431. Pojanath Bhatanacharoen et al., The Tipping Point of the 'TIPPING POINT' METAPHOR: AGENCY AND PROCESs For WAVES OF CHANGE 1 (2004), available at http://www.dur.ac.uk/resources/ihrr/tippingpoints/OLKC PaperforIHRR.pdf. The tipping point is defined as follows:

The term 'tipping point' in its most basic meaning refers to a critical point when unprecedented changes occur rapidly with irreversible effect. It entered the academic lexicon when it was used by the political scientist Morton Grodzins in 1957 in his sociological studies on racial segregation to describe the critical threshold at which point the white population would leave an area where more and more black people were present.

Id. at 1 . The phrase was coined by analogy to physics where "[a]dding a small amount of weight to a balanced object can cause it to suddenly and completely topple." Mark Heley, The Global Tipping Point, NeTPLACES.COM, http://www. netplaces.com/guide-to-2012/the-chaos-point-and-the-noosphere/the-globaltipping-point.htm (last visited Jan. 26, 2013). Heley further defines the tipping point as when "change in a complex system becomes unstoppable. This tends to happen quickly and abruptly, rather than gradually and incrementally." Id. However, the phrase "the tipping point" was more widely popularized by Malcolm Gladwell's 2000 bestseller. MALCOLM GLADWELL, THE TIPPING PoinT: How LiTTle Things CAN MAKE A Big DifFEREnCE 19 (1st ed. 2000). Gladwell defines the "tipping point" as "the moment of critical mass, the threshold, the boiling point," at which changes within society, businesses, and science become irreversible. $I d$. at 12 .

432. The notion of "a tiny percentage of people do[ing] the majority of the work" is what economists call the 80/20 principle. GLADWELL, supra note 431, 
Hopefully, that tipping point is right around the corner. Anything else would be unacceptable.

at 19. This principle describes the notion that "in any situation roughly 80 percent of the 'work' will be done by 20 percent of the participants." Id. 